Publisher: GSA

Journal: GEOL: Geology

DOI:10.1130/G39344.1

\title{
Southwestern Africa on the burner: Pleistocene carbonatite volcanism linked to deep mantle upwelling in Angola
}

Andrea Giuliani 1,2,3, *, Marc Campeny 4,5, Vadim S. Kamenetsky 6, Juan Carlos Afonso 2,7, Roland Maas 1, Joan Carles Melgarejo 5, Barry P. Kohn 1, Erin L., Matchan 1, José Mangas 8, Antonio 0. Gonçalves 9, José Manuel 9

1 School of Earth Sciences, The University of Melbourne, Parkville, VIC 3010, Australia

2 ARC Centre of Excellence for Core to Crust Fluid Systems and GEMOC, Department of Earth and Planetary Sciences, Macquarie University, NSW 2109, Australia

3 Department of Earth Sciences, Vrije Universiteit Amsterdam, 1081 HV Amsterdam, The Netherlands

4 Natural History Museum of Barcelona, 08003 Barcelona, Catalonia, Spain

5 Department Mineralogia, Petrologia i Geologia Aplicada, Universitat de Barcelona, 08028 Barcelona, Catalonia, Spain

6 School of Physical Sciences, University of Tasmania, Hobart, Tasmania 7001, Australia

7 Centre for Earth Evolution and Dynamics, Department of Geosciences, University of Oslo

8 Department Física, Instituto de Oceanografía y Cambio Global, Universidad de Las Palmas de Gran Canaria, Campus universitario de Tafira, 35017 Las Palmas de Gran Canaria, Spain

9 Departament Geologia, Universidade Agostinho Neto, 815 Luanda, Angola

*E-mail addresses: andrea.giuliani@unimelb.edu.au; andrea.giuliani@mq.edu.au; telephone: +61-3-83449094 


\section{ABSTRACT}

The origin of intraplate carbonatitic to alkaline volcanism in Africa is controversial. A tectonic control, i.e., decompression melting associated far-field stress, is suggested by correlation with lithospheric sutures, repeated magmatic cycles in the same areas over several Myr, synchronicity across the plate, and lack of clear age progression patterns. Conversely, a dominant role for mantle convection is supported by the coincidence of Cenozoic volcanism with regions of lithospheric uplift, positive free-air gravity anomalies and slow seismic velocities. To improve constraints on the genesis of African volcanism, here we report the first radiometric and isotopic results for the Catanda complex, which hosts the only extrusive carbonatites in Angola. Apatite (U-Th-Sm)/He and phlogopite $40 \mathrm{Ar} / 39 \mathrm{Ar}$ ages of Catanda aillikite lavas indicate eruption at $\sim 500-800 \mathrm{ka},>100 \mathrm{Ma}$ after emplacement of abundant kimberlites and carbonatites in this region. The lavas share similar HIMU-like $\mathrm{Sr}-\mathrm{Nd}$-Pb-Hf isotope compositions with other young mantle-derived volcanics from Africa (e.g., Northern Kenya Rift; Cameroon Line). The position of the Catanda complex in the Lucapa corridor, a long-lived extensional structure, suggests a possible tectonic control for the volcanism. The complex is also located on the Bié Dome, a broad region of fast Pleistocene uplift attributed to mantle upwelling. Seismic tomography models indicate convection of deep hot material beneath regions of active volcanism in Africa including a large area encompassing Angola and northern Namibia. This is strong evidence that intraplate late-Cenozoic volcanism, including the Catanda complex, resulted from the interplay between mantle convection and pre-existing lithospheric heterogeneities.

\section{INTRODUCTION}

Cenozoic volcanism is widespread in Africa, with prominent examples such as the Eastern African Rift System (EARS), the Cameroon Line, Darfur, Hoggar, Tibesti and the Moroccan Atlas (Fig. 1) (e.g., Wilson and Guiraud, 1992; Burke, 1996; Ebinger and Sleep, 1998; Njome and de Wit, 2014). The magmatic products commonly derive from the mantle and range from carbonatitic and mafic alkaline to differentiated silica-rich magmas (e.g., Wilson and Guiraud, 1992; Bailey and Woolley, 2005). Most magmatic centers are located along suture zones between tectonic terranes (e.g., Thorpe and Smith, 1974). A profound lithospheric control on intraplate volcanism, whereby melts are generated by decompression-induced melting in (or below) the lithosphere due to extensional stress, is indicated by 1) association of volcanism with terrane, boundaries and/or thin lithosphere; 2) cyclicity of magmatic activity in the same regions over $>100 \mathrm{Myr}$; 3 ) synchronicity across the African plate; and 4) absence of clear age progression patterns (Bailey and Woolley, 2005). The 
only notable exceptions are Late Cretaceous and Paleogene alkaline volcanic centers in southern Namibia, possibly related to the passage of hot spots currently in the South Atlantic (Reid et al., 1990). Regions of active and recent volcanism coincide with some of the several swells (i.e., topographic highs) that characterize the surface morphology of the African continent (e.g., Burke, 1996). These zones are characterized by positive free-air gravity anomalies (e.g., Burke, 1996; Al-Hajri et al., 2009) and slow seismic velocities in the mantle (e.g., Forte et al., 2010; French and Romanowicz, 2015), suggesting that sublithospheric convection plays a significant role in sustaining the high topography of the swells and triggering intraplate volcanism (Fishwick and Bastow, 2011). With evidence for tectonic, lithospheric and convective controls, the ultimate trigger(s) of mantle-derived Cenozoic intraplate volcanism in Africa remains unresolved.

To contribute to this discussion, we report the first geochronological and radiogenic isotope results for aillikite (i.e., carbonate-rich ultramafic lamprophyre) lavas from the Catanda volcanic complex in central Angola (Fig. 1 and Fig. DR1 inSupplementary Material). This complex also includes the only extrusive carbonatites documented in Angola to date (Campeny et al., 2014, 2015). The well-preserved volcanic morphology and ongoing hydrothermal activity in the Catanda area (i.e., small mud volcanoes and abundant travertine occurrences; Fig. DR2) suggest that volcanism is considerably younger than a nearby nephelinitic dyke which was dated at $92 \pm 7$ Ma by whole rock K-Ar dating (Torquato and Amaral, 1973).

Catanda is located on the Bié Dome, along the NW margin of the Lucapa corridor(Fig. 1), a $>1000 \mathrm{~km}$-long NE-SW oriented graben structure. The corridor records magmatic (including kimberlites and intrusive carbonatites) and tectonic activity in the Neoproterozoic, Permo-Triassic and in the Cretaceous between 145 and 100 Ma (e.g., Allsopp and Hargraves, 1985; Jelsma et al., 2009, 2013).

Earthquakes of magnitude up to 5.1 M (including three in the Catanda area between 1989 and 2014; https://earthquake.usgs.gov/) suggest ongoing tectonism in the corridor (Fig. DR3). The Bié Dome is a large plateau ( 1000 km in diameter; $\sim 2500 \mathrm{~m}$ of elevation) formed during major phases of uplift in the Oligocene and Pleistocene (including unusually fast ( $\sim 2 \mathrm{~mm} / \mathrm{yr}$ ) uplift in the last $1 \mathrm{Myr}$ ), probably triggered and supported by mantle upwelling (Al-Hajri et al., 2009; Walker et al., 2016). Mantle convection models indeed show active upwelling beneath an area straddling Angola and northern Namibia (Forte et al., 2010). Several lines of geophysical evidence indicate that the Catanda area is underlain by thinner lithosphere ( $\leq 140 \mathrm{~km}$ ) than inland Angola (>160 km; Fig. 1) (Globig et al., 2016). The Catanda complex therefore provides an excellent opportunity to test the possible 
interplay between mantle convection and pre-existing lithospheric structures in the formation of intraplate magmas.

\section{GEOLOGICAL SETTING}

In the Lucapa corridor carbonatitic volcanism is restricted near the village of Catanda (Fig. 1). The Catanda complex consists of a cluster of small volcanic edifices with maar and tuff ring morphologies covering an area of $50 \mathrm{~km} 2$. The complex comprises pyroclastic rocks with subordinate calciocarbonatite, altered natrocarbonatite and aillikite lavas (Fig. DR1), which together form volcanic successions up to $100 \mathrm{~m}$ thick (Campeny et al., 2014, 2015). Fresh surface samples from three lava flows (AC-21, -24 and -25) in the Ungongué volcanic succession (Fig. DR1), whose petrography, mineral and bulk-rock compositions were reported by Campeny et al. (2015), were selected for this study. The samples exhibit a porphyritic texture and contain variable proportions of 0.5-2.0 mm-sized phenocrysts of fluorapatite, titanomagnetite, Ti-rich clinopyroxene, Ti-rich phlogopite partially altered to vermiculite, and serpentinised olivine in a calcite-rich groundmass (Fig. DR4).

Based on their compositional and mineralogical features, these lavas are classified as aillikites. The lavas contain occasional glimmerite (i.e., phlogopite-dominated) xenoliths probably sourced from the lithospheric mantle.

\section{RESULTS}

\section{Age Constraints}

Initial attempts to constrain the age of Catanda lavas by apatite $\mathrm{U}-\mathrm{Th}-\mathrm{Pb}$ and phlogopite $\mathrm{Rb}$ Sr dating did not provide conclusive results because of limited radiogenic ingrowth (see Supplementary Material). Robust age constraints are provided by (U-Th-Sm)/He (AHe) dating of nine apatite aliquots from lavas AC-21 and 25. Given the expected young age (and low $4 \mathrm{He}$ content) of the apatite grains, most of the AHe analyses were carried out on multigrain samples (see Methods in Supplementary Material), which yield weighted (U-Th$\mathrm{Sm}$ )/He ages of $640 \pm 130 \mathrm{ka}$ and $650 \pm 90 \mathrm{ka}$ (uncertainties at 95\% confidence level) for samples AC-21 and -25 , respectively (Table 1 ).

40Ar/39Ar dating of phlogopite grains (see Tables DR4-DR6 and Methods) from samples AC-24 and -25 yield similarly young results, which were pooled to produce an inverse isochron age of $558 \pm 22 \mathrm{ka}(2 \sigma ; \mathrm{n}=6$; Fig. 2). By contrast, phlogopite grains from sample AC-21 yield generally older apparent ages across all heating steps, and produce a weighted 
mean age of $741 \pm 44$ ka calculated by pooling concordant $40 \mathrm{Ar}^{*} / 39 \mathrm{Ar}$ results from the five analyzed grains (Fig. DR5). The corresponding inverse isochron for these data (Fig. 2) yields an age of $776 \pm 81 \mathrm{ka}$. Although the age difference between samples AC-21 and $24 / 25$ is statistically significant, partial alteration of phlogopite to vermiculite, coupled with the possible occurrence of mica xenocrysts (as suggested by glimmerite xenoliths) in Catanda lavas warrant cautious treatment of these results.

Nevertheless, the phlogopite 40Ar/39Ar ages overlap with the apatite AHe ages, and support a Middle Pleistocene age for the volcanism.

\section{Radiogenic Isotopes}

Clinopyroxene, apatite and groundmass fractions of the Catanda lavas have high $206 \mathrm{~Pb} / 204 \mathrm{~Pb}(>20)$, low ${ }_{87} \mathrm{Sr} / 86 \mathrm{Sr}(\leq 0.7035)$, and moderately high ${ }_{143} \mathrm{Nd} /{ }_{144} \mathrm{Nd}(0.51278-$ 0.51286), reminiscent of HIMU-type ocean island basalts (OIB) such as St. Helena (Fig. 3, Figure DR6 and Table DR1). Isotopic compositions transitional between the HIMU and 'enriched' mantle (EM) components, are also found in other Cenozoic mantle-derived volcanic suites across the African continent (e.g., EARS carbonatites from the Northern Kenya Rift, Cameroon Line volcanics, Western Cape olivine melilitites; Fig. 3). We therefore suggest that aillikite (and carbonatite) magmas at Catanda represent a further example of mantle-derived, HIMU-like magmatism in Africa. A mantle origin is also supported by $\mathrm{C}$ isotope data for Catanda carbonates (Campeny et al., 2015).

\section{DISCUSSION AND CONCLUSIONS}

The young ( $\sim 500-800 \mathrm{ka})$ radiometric age of the Catanda lavas is consistent with other evidence for recent volcanic and geothermal activity in the Catanda area, including wellpreserved volcanic landforms and ongoing hydrothermal activity (Fig. DR2). These observations imply a recent resumption of volcanic activity in western Angola, some $90 \mathrm{Ma}$ after emplacement of mafic alkaline mafic dykes in the area (Torquato and Amaral, 1973; Marzoli et al., 1999). The position of the Catanda complex in the Lucapa corridor suggests that the local lithospheric architecture facilitated melt ascent to the surface.

Recent seismic activity (Fig. DR3) might support a tectonic trigger (i.e., far-field stress) for volcanism. However, the rapid Pleistocene uplift (Walker et al., 2016), the occurrence of positive free-air gravity anomalies (Fig. 1), seismic tomography and mantle convection models (Forte et al., 2010; French and Romanowicz, 2015), all support active mantle upwelling beneath the area and make unlikely a purely tectonic trigger for mantle-derived 
magmatism. Seismic tomography models (e.g., Ritsema et al., 1999; Forte et al., 2010; French and Romanowicz, 2015) suggest that a large dome of mantle material with slow seismic velocities, sourced from the core-mantle boundary beneath central-southern Africa (termed the "South African Superplume") ascends beneath the Kalahari and Congo cratons and splits into multiple branches once it reaches the upper mantle. The larger eastern branches of this deep structure feed the EARS, whereas the smaller western branches upwell beneath the Cameroon Line and a large area beneath northern Namibia and centralsouthern Angola, where Catanda is located. We speculate that rapid uplift of the Bié Dome and attendant Catanda carbonatitic-aillikitic volcanism in the Pleistocene might be related to a finger-like structure stemming from a branch of the South African Superplume that is upwelling beneath southwestern Africa. The recent global seismic tomography model of French and Romanowicz (2015, their Extended Fig. 3a) indeed shows a narrow structure with low surface-wave velocity beneath central Angola, which is connected to the top of a larger upwelling. A similar model was proposed to explain volcanism in the northern part of the EARS (Civiero et al., 2015) and Cenozoic intraplate magmatism in $\leq 500 \mathrm{~km}$-large zones of localized uplift across Europe (e.g., Wilson and Patterson, 2001). Thinned lithosphere beneath the Lucapa corridor and especially its western sector (Fig. 1) would provide a preferential pathway for focusing mantle upwelling as previously proposed by Fishwick and Bastow (2011) for other intraplate volcanic regions in northern Africa (e.g., Hoggar, Tibesti; Fig. 1).

Late Cretaceous mantle upwelling activity is suggested by mafic alkaline rocks with trace element and $\mathrm{Sr}$ isotope affinity to the St Helena OIBs (and similar $87 \mathrm{Sr} / 86 \mathrm{Sr}$ values to the Catanda lavas), which emplaced at 90-95 Ma along the central Angolan margin (Fig. 1) (Marzoli et al., 1999). Similar Sr-Nd isotope compositions for Catanda lavas, the 116-133 Ma Lunda Norte kimberlites (Castillo-Oliver et al., 2016) and Cretaceous carbonatites (Alberti et al., 1999) in the Lucapa corridor (Fig. 1) may indicate that Cretaceous kimberlites and carbonatites, and Pleistocene Catanda carbonatite-aillikite magmas have tapped similar (convective) mantle sources.

While the Catanda complex and other expressions of late Cenozoic intraplate volcanism in Africa (e.g., EARS, Cameroon Line, Darfur, Hoggar, Tibesti, Moroccan Atlas) correlate with pre-existing lithospheric discontinuities, they also show evidence of being affected by active mantle upwelling. We therefore argue that intraplate carbonatitic and alkaline magmatism result from the complex interplay between multi-scale mantle convection and pre-existing lithospheric structures, as previously proposed for Cenozoic volcanism in the North China Craton (Guo et al., 2016), rather than being controlled by tectonic processes alone (e.g., continental break-up, changes in direction and speed of plate motion). We recognize that current models of mantle convection do not readily explain the recurrence 
of volcanism in specific areas of Africa over $>100 \mathrm{Myr}$, for example in the Rungwe zone of the EARS (Bailey and Woolley, 2005), in the continental sector of the Cameroon Line (Njome and de Wit, 2014) and in the Lucapa corridor (this study). Future models of mantle dynamics will need to incorporate these observations to address the question of whether upwelling of asthenospheric material can be the main driver of intraplate carbonatitic and alkaline magmatism in Africa and elsewhere.

\section{ACKNOWLEDGMENTS}

This work was supported by the consolidated research group SGR-444 and -1661 of the Catalonia Government, the Spanish Government (research project n. CGL2009-13758), the Society of Economic Geologists (Hugh E. McKinstry fund), and the Australian Research Council (DE150100009 to AG,DP130100257 to VSK and DP160103502 to JCA). We thank José Fortuna and Felipe Correia from Catanda village for their assistance during field-work; Mark Kendrick, David Phillips and Gareth Davies for informal reviews of an earlier version of this manuscript; and Louis Moresi, Ting Yang and Mike Sandiford for insightful discussions. This manuscript was significantly improved by constructive reviews from Cynthia Ebinger, Phil Janney and an anonymous reviewer, and the encouraging and helpful editorial handling of Dennis Brown.

\section{REFERENCES CITED}

Al-Hajri, Y., White, N., and Fishwick, S., 2009, Scales of transient convective support beneath Africa: Geology, v. 37, p. 883-886.

Alberti, A., Castorina, F., Censi, P., Comin-Chiaramonti, P., and Gomes, C.B., 1999, Geochemical characteristics of Cretaceous carbonatites from Angola: Journal of African Earth Sciences, v. 29, p. 735-759, doi:10.1016/S0899-5362(99)00127-X.

Allsopp, H.L., and Hargraves, R.B., 1985, Rb-Sr ages and palaeomagnetic data for some Angolan alkaline intrusives: Transactions - Geological Society of South Africa, v. 88, p. 295299.

Amante, C., and Eakins, B.W., 2009, ETOP01 Arc-Minute Global Relief Model: Procedures, Data Sources and Analysis.: NOAA Technical Memorandum NESDIS NGDC-24. 
Bailey, D.K., and Woolley, A.R., 2005, Repeated, synchronous magmatism within Africa: Timing, magnetic reversals, and global tectonics: Geological Society of America. Special Paper, v. 388, p. 365-377.

Bell, K., and Tilton, G.R., 2001, Nd, Pb and Sr Isotopic Compositions of East African Carbonatites: Evidence for Mantle Mixing and Plume Inhomogeneity: Journal of Petrology, v. 42, p. 1927-1945, doi:10.1093/petrology/42.10.1927.

Burke, K., 1996, The African Plate: South African Journal of Geology, v. 99, p. 341-409.

Campeny, M., Kamenetsky, V.S., Melgarejo, J.C., Mangas, J., Manuel, J., Alfonso, P., Kamenetsky, M.B., Bambi, A.C.J.M., and Gonçalves, A.O., 2015, Carbonatitic lavas in Catanda (Kwanza Sul, Angola): Mineralogical and geochemical constraints on the parental melt: Lithos, v. 232, p. 1-11, doi:10.1016/j.lithos.2015.06.016.

Campeny, M., Mangas, J., Melgarejo, J.C., Bambi, A., Alfonso, P., Gernon, T., and Manuel, J., 2014, The Catanda extrusive carbonatites (Kwanza Sul, Angola): An example of explosive carbonatitic volcanism: Bulletin of Volcanology, v. 76, p. 818, doi:10.1007/s00445-0140818-6.

Castillo-Oliver, M., Galí, S., Melgarejo, J.C., Griffin, W.L., Belousova, E., Pearson, N.J., Watangua, M., and O'Reilly, S.Y., 2016, Trace-element geochemistry and U-Pb dating of perovskite in kimberlites of the Lunda Norte province (NE Angola): Petrogenetic and tectonic implications: Chemical Geology, v. 426, p. 118-134, doi:10.1016/j.chemgeo.2015.12.014.

Chorowicz, J., 2005, The East African rift system: Journal of African Earth Sciences, v. 43, p. 379-410, doi:10.1016/j.jafrearsci.2005.07.019.

Civiero, C., Hammond, J.O.S., Goes, S., Fishwick, S., Ahmed, A., Ayele, A., Doubre, C., Goitom, B., Keir, D., Kendall, J.M., Leroy, S., Ogubazghi, G., Rümpker, G., and Stuart, G.W., 2015, Multiple mantle upwellings in the transition zone beneath the northern East-African Rift system from relative P-wave travel-time tomography: Geochemistry Geophysics Geosystems, v. 16, p. 2949-2968, doi:10.1002/2015GC005948.

Ebinger, C.J., and Sleep, N.H., 1998, Cenozoic magmatism throughout east Africa resulting from impact of a single plume: Nature, v. 395, p. 788-791, doi:10.1038/27417. 
Fishwick, S., and Bastow, I. D., 2011, Towards a better understanding of African topography: a review of passive-source seismic studies of the African crust and upper mantle: Geological Society, London, Special Publications, v. 357, p. 343-371, doi:10.1144/SP357.19

Forte, A.M., Quéré, S., Moucha, R., Simmons, N.A., Grand, S.P., Mitrovica, J.X., and Rowley, D.B., 2010, Joint seismic-geodynamic-mineral physical modelling of African geodynamics: A reconciliation of deep-mantle convection with surface geophysical constraints: Earth and Planetary Science Letters, v. 295, p. 329-341, doi:10.1016/j.epsl.2010.03.017.

French, S.W., and Romanowicz, B., 2015, Broad plumes rooted at the base of the Earth's mantle beneath major hotspots: Nature, v. 525, p. 95-99, doi:10.1038/nature14876.

Globig, J., Fernàndez, M., Torne, M., Vergés, J., Robert, A., and Faccenna, C., 2016, New insights into the crust and lithospheric mantle structure of Africa from elevation, geoid, and thermal analysis: Journal of Geophysical Research. Solid Earth, v. 121, p. 5389-5424, doi:10.1002/2016JB012972.

Guo, Z., Afonso, J.C., Qashqai, M.T., Yang, Y., and Chen, Y.J., 2016, Thermochemical structure of the North China Craton from multi-observable probabilistic inversion: Extent and causes of cratonic lithosphere modification: Gondwana Research, v. 37, p. 252-265, doi:10.1016/j.gr.2016.07.002.

Janney, P.E., Le Roex, A.P., Carlson, R.W., and Viljoen, K.S., 2002, A Chemical and MultiIsotope Study of the Western Cape Olivine Melilitite Province, South Africa: Implications for the Sources of Kimberlites and the Origin of the HIMU Signature in Africa: Journal of Petrology, v. 43, p. 2339-2370, doi:10.1093/petrology/43.12.2339.

Jelsma, H., Barnett, W., Richards, S., and Lister, G., 2009, Tectonic setting of kimberlites: Lithos, v. 112, p. 155-165, doi:10.1016/j.lithos.2009.06.030.

Jelsma, H., Krishnan, U., Perritt, S., Preston, R., Winter, F., Lemotlo, L., van der Linde, G., Armstrong, R., Phillips, D., Joy, S., Costa, J., Facatino, M., Posser, A., Kumar, M., Wallace, C., Chinn, I., and Henning, A., 2013, Kimberlites from Central Angola: A Case Study of Exploration Findings, in Pearson, D. G., et al., eds., Proceedings of 10th International Kimberlite Conference: Volume 2: New Delhi, Springer India, p. 173-190. 
Lee, D.-C., Halliday, A.N., Fitton, J.G., and Poli, G., 1994, Isotopic variations with distance and time in the volcanic islands of the Cameroon line: Evidence for a mantle plume origin: Earth and Planetary Science Letters, v. 123, p. 119-138, doi:10.1016/0012-821X(94)90262-3.

Marzoli, A., Melluso, L., Morra, V., Renne, P.R., Sgrosso, I., D’Antonio, M., Duarte Morais, L., Morais, E.A.A., and Ricci, G., 1999, Geochronology and petrology of Cretaceous basaltic magmatism in the Kwanza basin (western Angola), and relationships with the ParanàEtendeka continental flood basalt province: Journal of Geodynamics, v. 28, p. 341-356, doi:10.1016/S0264-3707(99)00014-9.

Njome, M.S., and de Wit, M.J., 2014, The Cameroon Line: Analysis of an intraplate magmatic province transecting both oceanic and continental lithospheres: Constraints, controversies and models: Earth-Science Reviews, v. 139, p. 168-194,

doi:10.1016/j.earscirev.2014.09.003.

Reid, D.L., Cooper, A.F., Rex, D.C., and Harmer, R.E., 1990, Timing of post-Karoo alkaline volcanism in southern Namibia: Geological Magazine, v. 127, p. 427-433, doi:10.1017/S001675680001517X.

Ritsema, J., van Heijst, H.J., and Woodhouse, J.H., 1999, Complex Shear Wave Velocity Structure Imaged Beneath Africa and Iceland: Science, v. 286, p. 1925-1928, doi:10.1126/science.286.5446.1925.

Stracke, A., 2012, Earth's heterogeneous mantle: A product of convection-driven interaction between crust and mantle: Chemical Geology, v. 330-331, p. 274-299, doi:10.1016/j.chemgeo.2012.08.007.

Thorpe, R.S., and Smith, K., 1974, Distribution of Cenozoic volcanism in Africa: Earth and Planetary Science Letters, v. 22, p. 91-95, doi:10.1016/0012-821X(74)90068-5.

Torquato, J.R., and Amaral, G., 1973, Algumas idades K/Ar do magmatismo mesozoico de Angola e sua correlação com o correspondente do sul do Brasil: Boletim do Instituto de Investigacão Científica de Angola, v. 10, p. 31-38.

Walker, R.T., Telfer, M., Kahle, R.L., Dee, M.W., Kahle, B., Schwenninger, J.L., Sloan, R.A., and Watts, A.B., 2016, Rapid mantle-driven uplift along the Angolan margin in the late Quaternary: Nature Geoscience, v. 9, p. 909-914, doi:10.1038/ngeo2835. 
Wilson, M., and Guiraud, R., 1992, Magmatism and rifting in Western and Central Africa, from Late Jurassic to Recent times: Tectonophysics, v. 213, p. 203-225, doi:10.1016/00401951(92)90259-9.

Wilson, M., and Patterson, R., 2001, Intraplate magmatism related to short-wavelength convective instabilities in the upper mantle: Evidence from the Tertiary-Quaternary volcanic province of Western and Central Europe: Geological Society of America. Special Paper, v. 352, p. 37-58.

\section{FIGURE CAPTIONS}

Figure 1. Elevation map of the African plate from the ETOP01 global model (Amante and Eakins, 2009) showing major tectonic and volcanic features. Major structural features of the East Africa Rift System (EARS) are from Chorowicz (2005). Inset shows location of the Catanda Complex, Lucapa Corridor, Kwanza seamounts, and major Triassic and Cretaceous kimberlite, carbonatite and alkali basalt occurrences (Marzoli et al., 1999; Jelsma et al., 2013; Castillo-Oliver et al., 2016). Grey shaded area indicates free-air, crust-corrected positive gravity anomaly above $15 \mathrm{mGal}$ (after Forte et al., 2010). Lithospheric thickness estimates (dashed red lines) are from Globig et al. (2016).

Figure 2. 40Ar/39Ar phlogopite inverse isochrons for Catanda lavas. The chart includes the inverse isochrons for data combined from samples AC-24 and AC-25 (blue symbols),assuming a J-value of $0.00104689 \pm 0.037 \%$ (AC-25-PHL value); and for AC-21 results with concordant 40Ar*/39Ar ratios (red symbols; J-value of $0.000105030 \pm$ $0.036 \%$ ). Rejected steps (i.e., low-T heating steps from grain AC-21PHL-1) are shown in gray in the inset.

Figure 3. (a) $87 \mathrm{Sr} / 86 \mathrm{Sr}$ vs $143 \mathrm{Nd} / 144 \mathrm{Nd}$, and (b) $206 \mathrm{~Pb} / 204 \mathrm{~Pb}$ vs $87 \mathrm{Sr} / 86 \mathrm{Sr}$ compositions of Catanda lavas compared to East Africa Rift System (EARS) carbonatites from the Northern and Southern Kenya Rifts (NKR, SKR) (Bell and Tilton, 2001), lavas from the Cameroon Line (Lee et al., 1994), Western Cape melilitites (Janney et al., 2002), HIMU

OIB lavas from St Helena and enriched-mantle (EM) OIB end-members (Stracke, 2012). The following solution-mode multi-collector ICP-MS analyses are reported in each panel: (a) clinopyroxene (3 analyses), apatite (3); and (b) apatite (1), combined groundmass ( $\mathrm{Pb}$ isotopes) and clinopyroxene ( $\mathrm{Sr}$ isotopes) from the same sample (3). 
1GSA Data Repository item 2017xxx, xxxxxxxx, is available online at http://www.geosociety.org/datarepository/2017/ or on request from editing@geosociety.org

TABLE 1. (U-TH-SM)/HE AGES OF APATITE

GRAINS IN SAMPLES AC-21 AND -25 FROM THE CATANDA COMPLEX

Sample 4He (ncc) Th/U Age (ka \pm 2 回)

AC-21_1 $0.047 \quad 11.86 \quad 690 \pm 40$

AC-21_2 $\quad 0.078 \quad 12.88 \quad 890 \pm 50$

AC-21_3 $\quad 0.166 \quad 12.26 \quad 580 \pm 30$

AC-21_4 $0.208 \quad 13.29 \quad 570 \pm 30$

AC-21_5 $0.035 \quad 15.75 \quad 650 \pm 40$

*Mean $64 \pm 130$

AC-25_1 $0.017 \quad 13.34 \quad 640 \pm 40$

AC-25_2 $\quad 0.044 \quad 8.82 \quad \dagger 1330 \pm 80$

AC-25_3 $\quad 0.075 \quad 11.60 \quad 630 \pm 40$

AC-25_4 $\quad 0.029 \quad 11.39 \quad 760 \pm 50$

AC-25_5 $\quad 0.068 \quad 11.35 \quad 620 \pm 40$

*Mean $650 \pm 90$

Notes: *Weighted mean age calculated at $95 \%$ c.i.

†Analysis excluded from calculation of weighted mean age. Between 1 and 7 grains were analyzed for each sample. See Supplementary Material for further information 


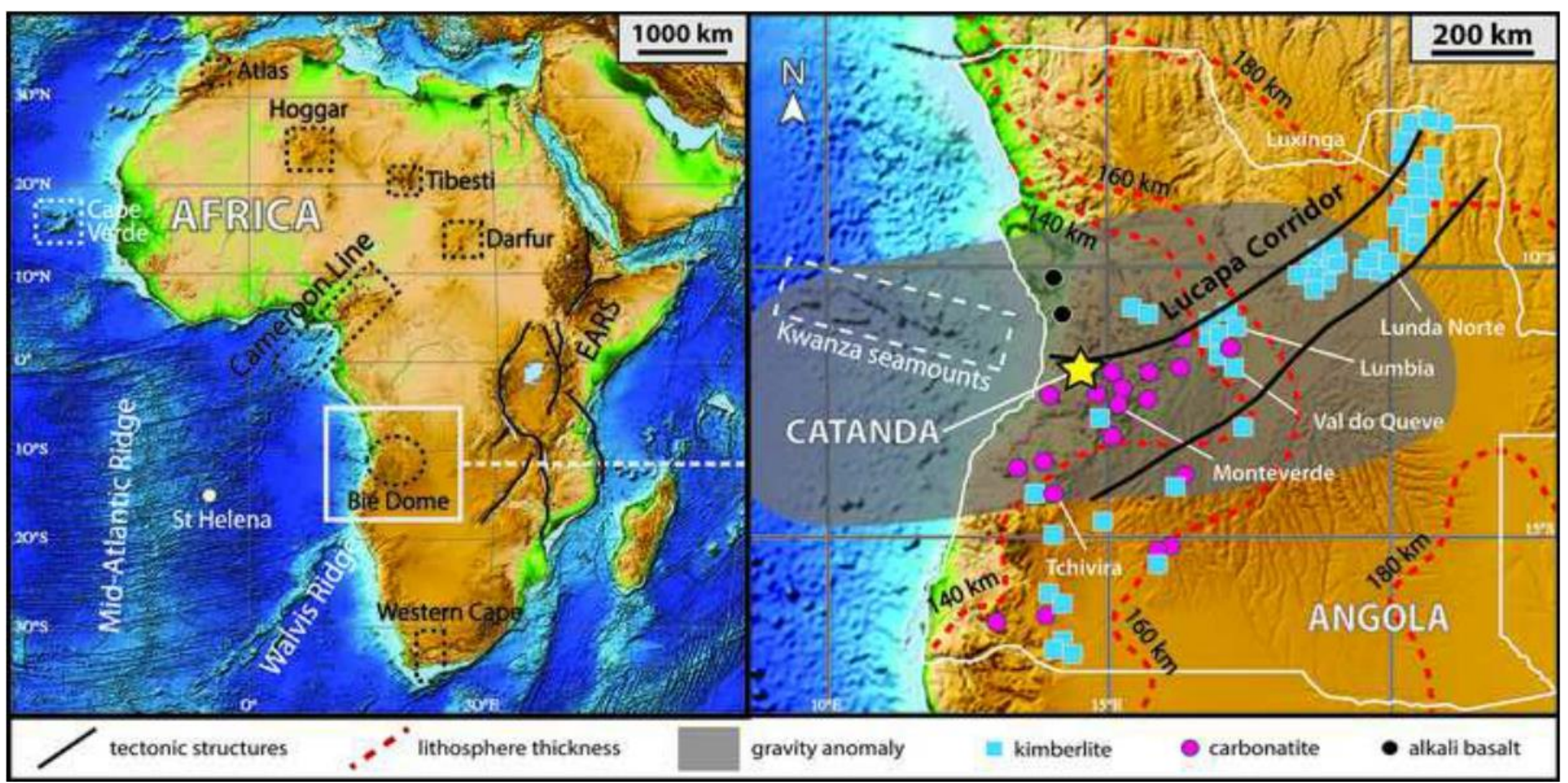


data-point error ellipses are $2 \sigma$

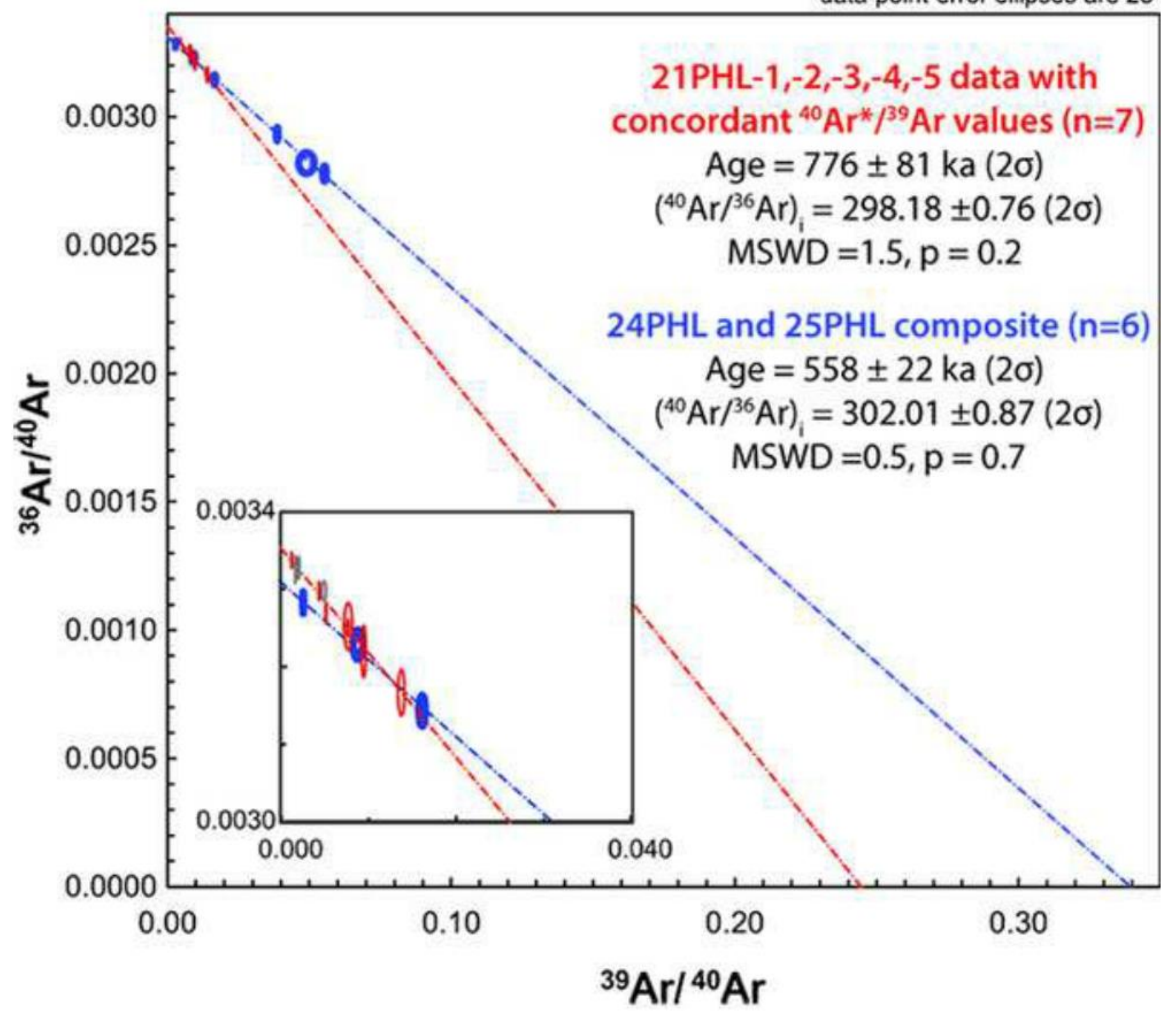




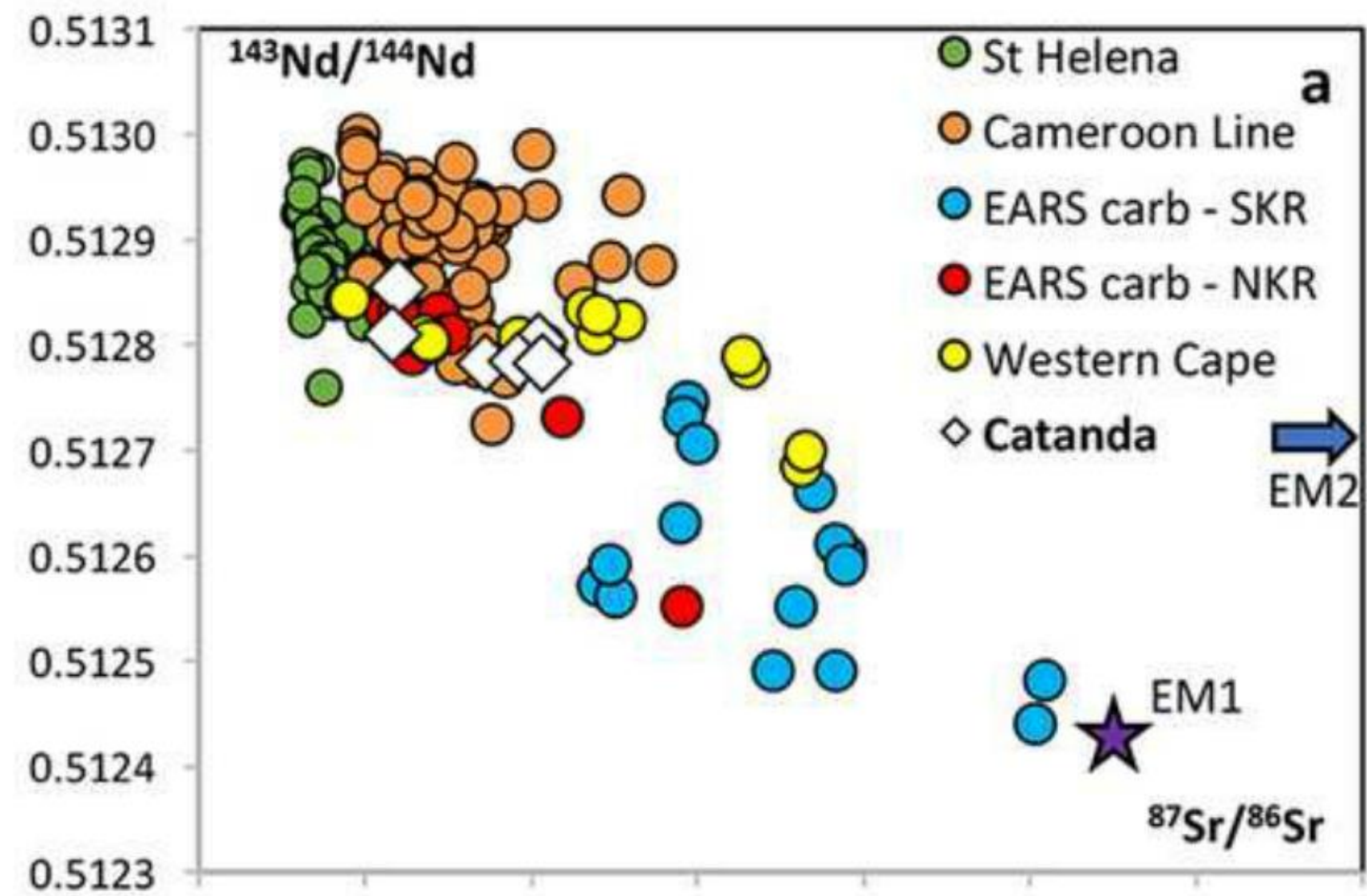

$\begin{array}{llllllll}0.7025 & 0.7030 & 0.7035 & 0.7040 & 0.7045 & 0.7050 & 0.7055 & 0.7060\end{array}$

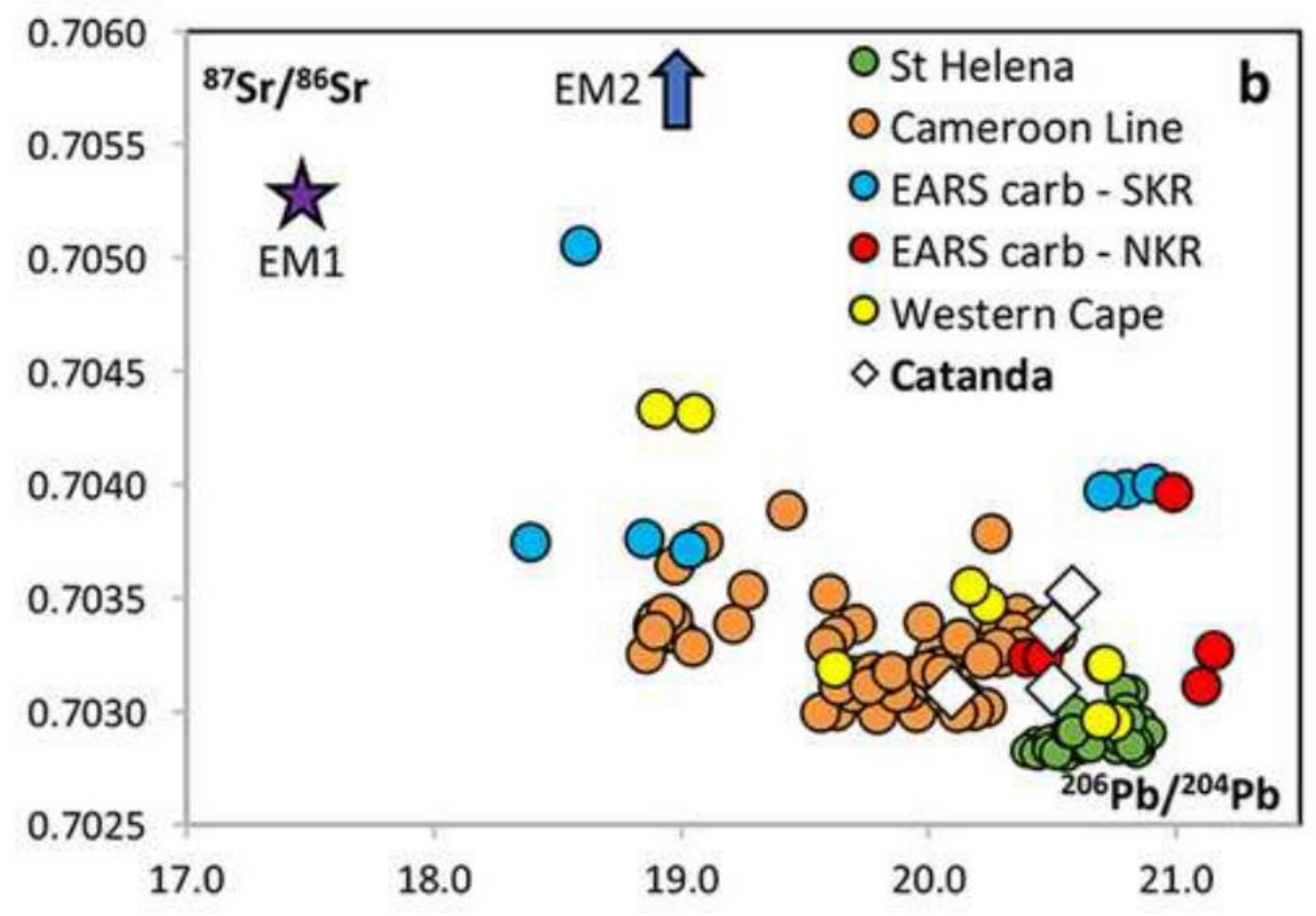




\section{SUPPLEMENTARY FIGURES}

\section{Figure DR1}

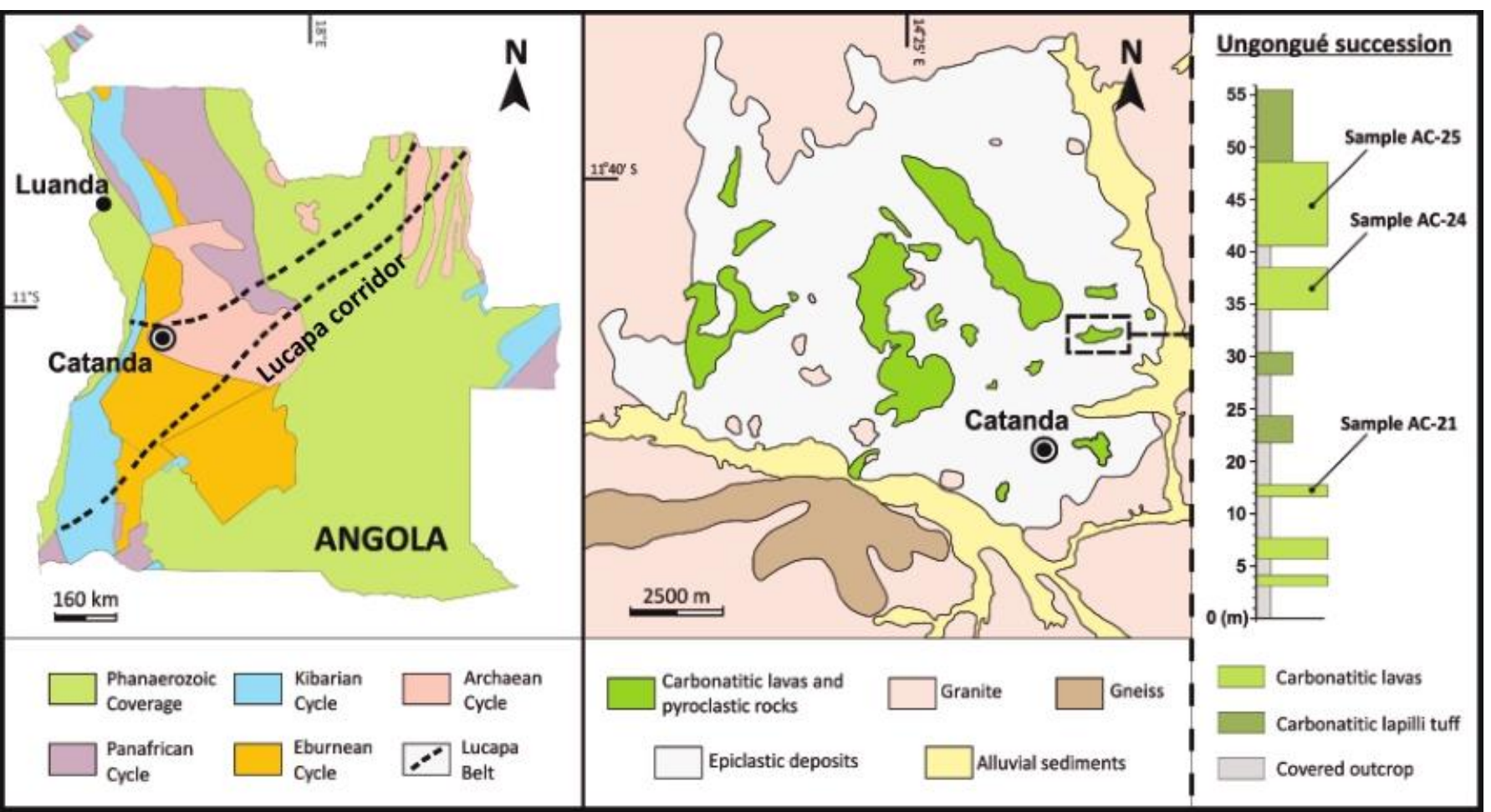

Supplementary figure DR1. Schematised geological map of Angola and the Catanda volcanic area and detailed volcano-stratigraphic succession of the Ungongué succession (modified from Campeny et al., 2014 Lithos). The location of the volcanic flows examined in this study is also included. 


\section{Figure DR2}
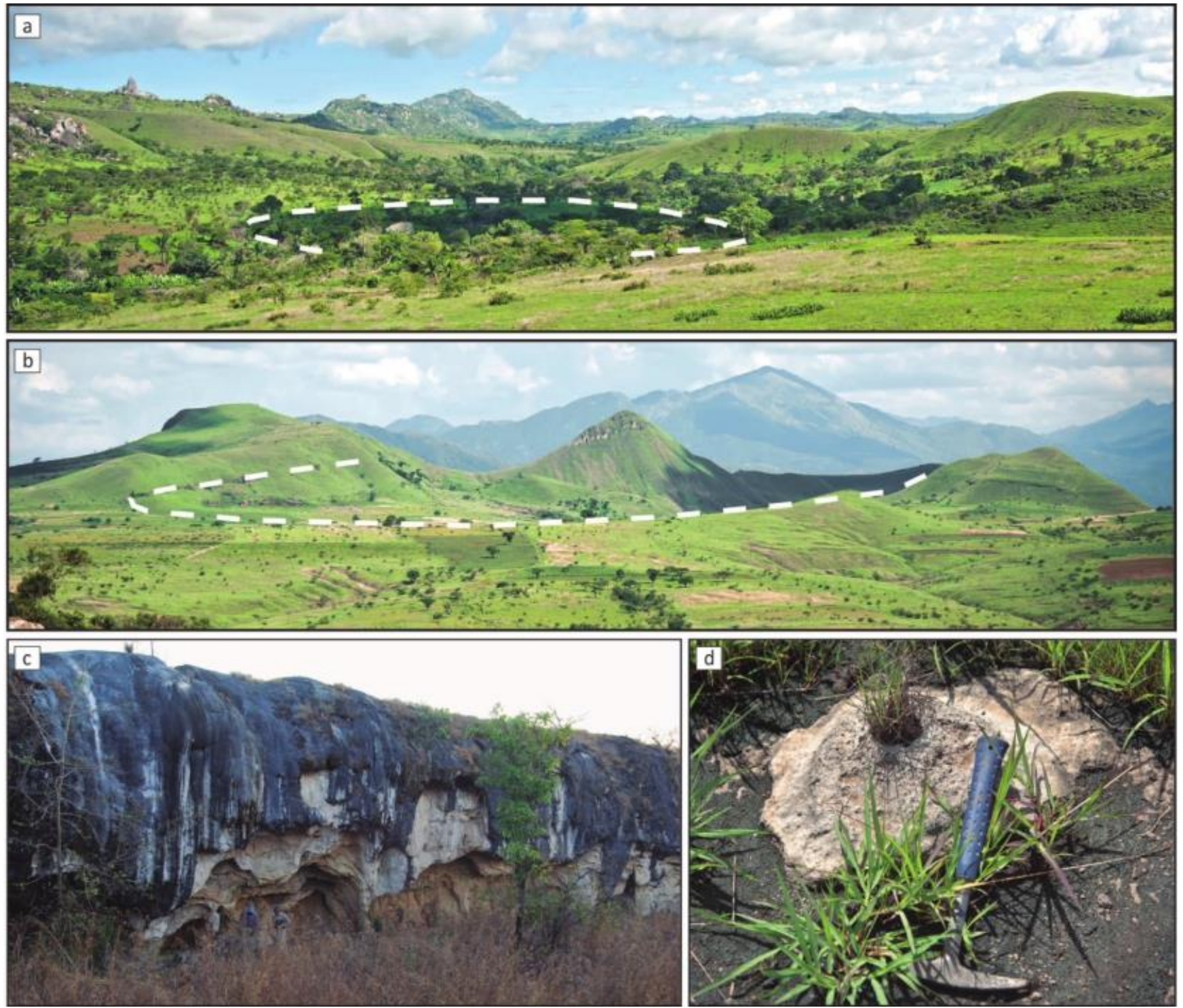

Supplementary figure DR2. Surface features of the Catanda volcanic complex. (a), (b) Wellpreserved morphology of the eruptive centres (volcanic cones, maars - see dotted lines). (c) Travertine deposits up to $30 \mathrm{~m}$ thick, associated with present-day hydrothermal systems in the Catanda area. (d) Products of recent, small-scale carbonate mud (mini-) eruption. 


\section{Figure DR3}

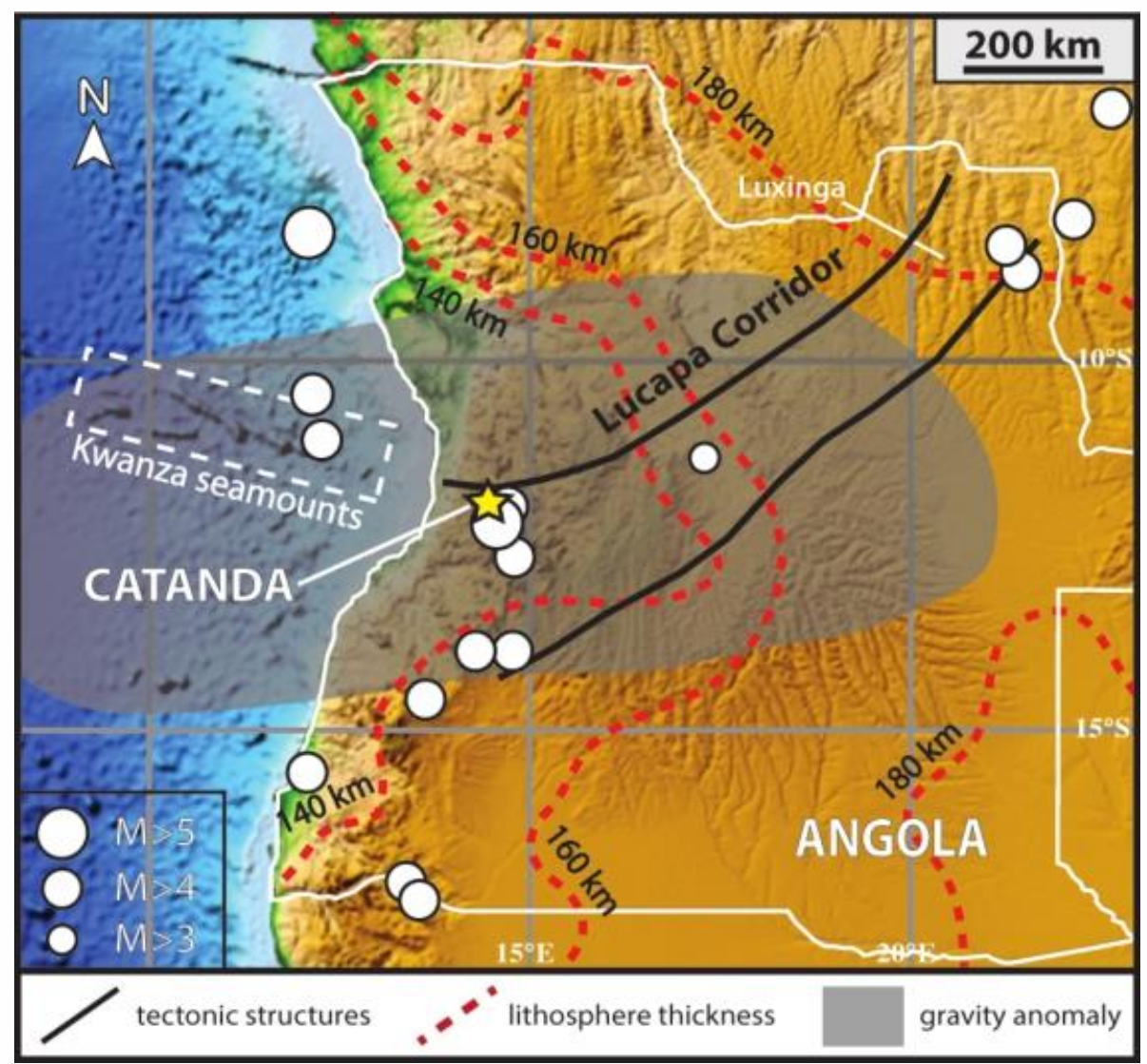

Supplementary figure DR3. Elevation map of Angola from the ETOPO1 global model (Amante and Eakins, 2009) showing the location of historical eartquakes (i.e after 1900) of magnitude above 2.5M (source https://earthquake.usgs.gov/2. The approximate boundaries of the Lucapa corridor are also shown. Grey shaded area indicates free-air, crust-corrected positive gravity anomaly above 15 mGal (after Forte et al., 2010). Lithospheric thickness estimates (dashed red lines) are from Globig et al. (2016). 


\section{Figure DR4}

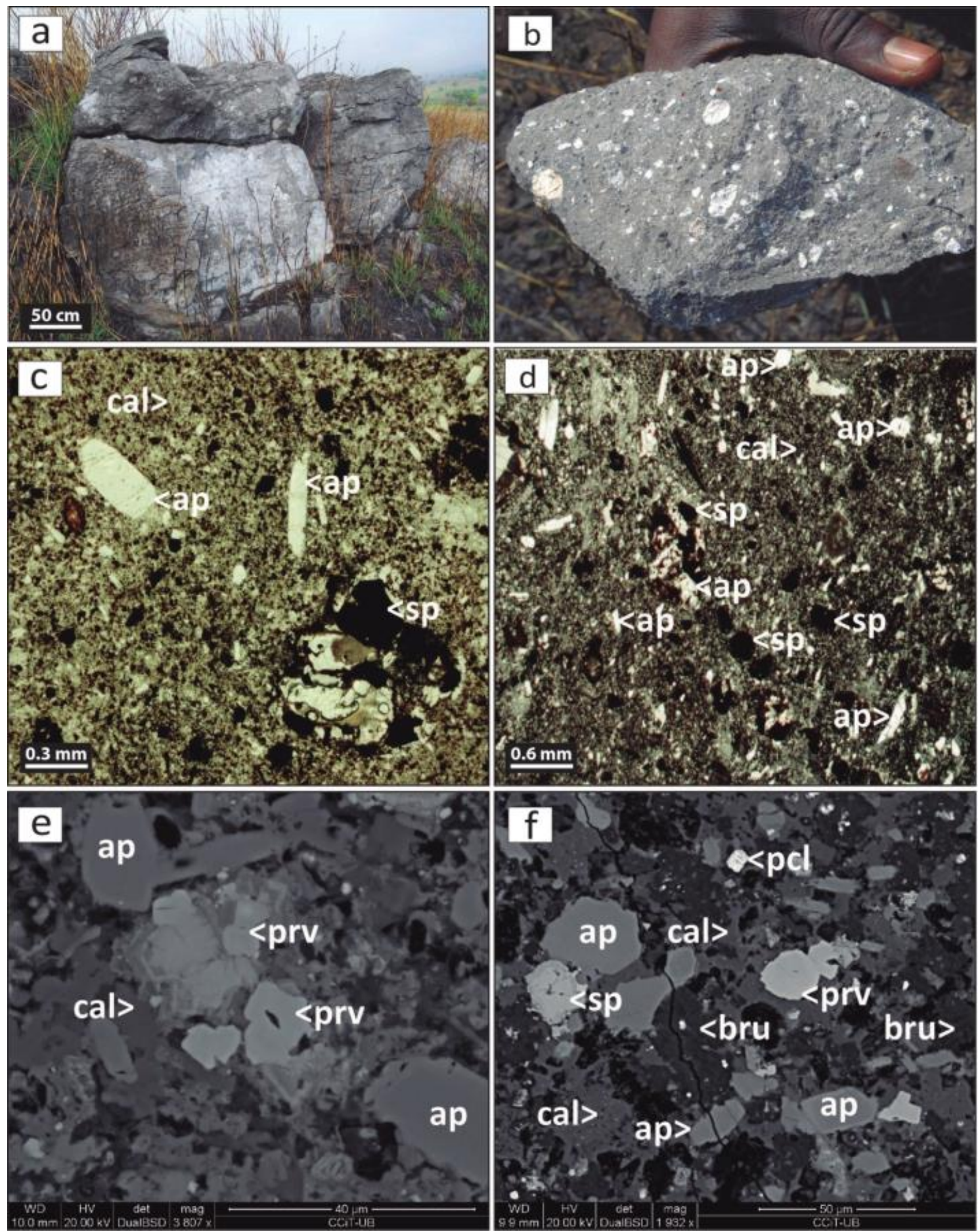

Supplementary figure DR4. Outcrop, hand specimen and petrographic images of Catanda carbonatitic-aillikitic lavas. (a) Photograph of lava flow in the upper part of the Ungongué succession; (b) porphyritic sample of lava from the Ungongué volcanic sequence; (c), (d) transmittedlight photomicrographs of porphyritic lavas with apatite (ap) and spinel (sp) micro-phenocrysts hosted in a groundmass dominated by calcite (cal); (e), (f) scanning electron microscope (SEM), backscattered electron (BSE) images of lava groundmass, which contains apatite (ap), perovskite (prv), calcite (cal), brucite (bru) and accessory euhedral crystals of pyrochlore (pcl). 
Figure DR5

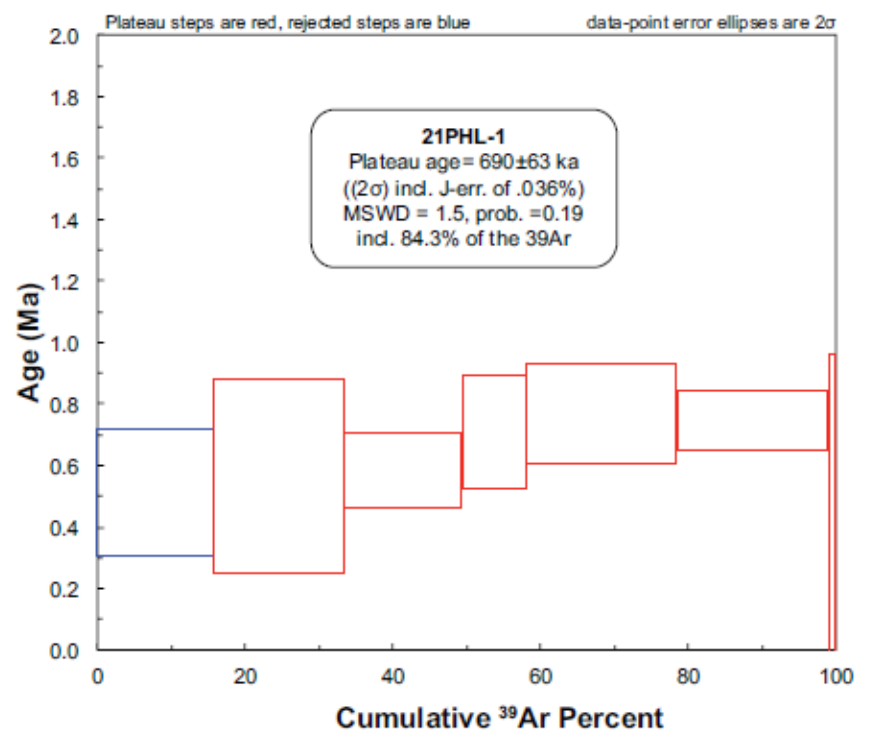

Supplementary figure DR5.' $40 \mathrm{Ar} / 39 \mathrm{Ar}$ phlogopite age spectrúm for grain 21PHL-1. 

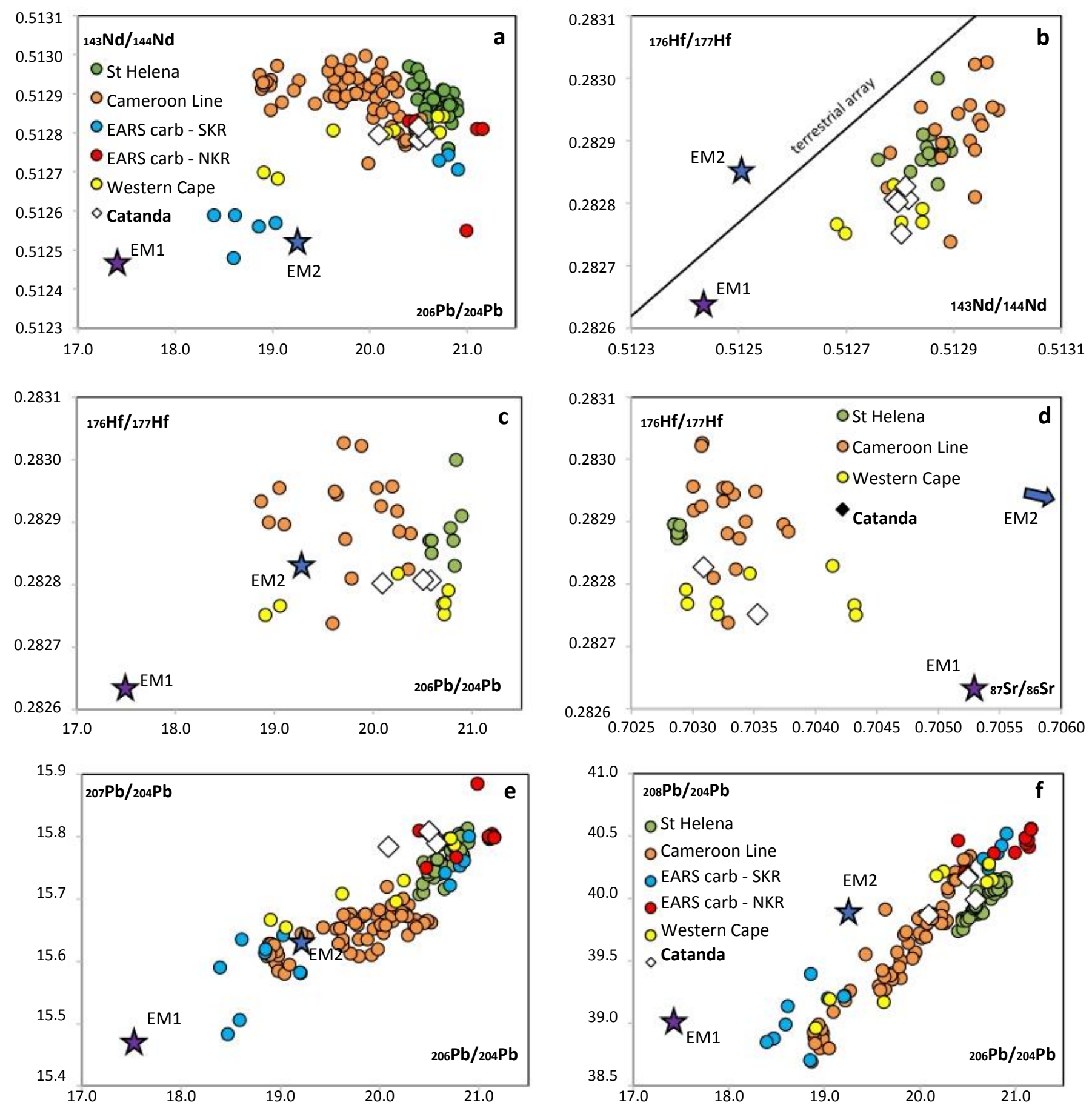

Supplementary figure DR6. Radiogenic isotope compositions of Catanda lavas (additional charts). The Catanda values are compared to the isotopic compositions of Eastern Africa Rift System (EARS) carbonatites from the Northern and Southern Kenya Rifts (NKR, SKR) (Bell and Tilton, $2001 \mathrm{~J} \mathrm{Petrol),}$ lavas from the Cameroon Line (Lee et al., 1994 EPSL; Ballentine et al., 1997 Chem Geol), Western Cape melilitites (Janney et al., $2002 \mathrm{~J}$ Petrol), HIMU OIB lavas from St Helena (Stracke, 2012 Chem Geol), and enriched-mantle (EM) OIB end-members represented by the most extreme compositions of lavas from Pitcairn (EM-1) and Samoa (EM-2) (Stracke, 2012). The following solution-mode multicollector ICP-MS analyses are reported in each panel: $(\mathbf{a}, \mathbf{e}, \mathbf{f})$ bulk groundmass ( 3 analyses), apatite (1); (b) groundmass (3) and clinopyroxene (1); (c) groundmass (3); (d) clinopyroxene (2). In (c), the terrestrial array is from Vervoort et al. (2011 GCA). 


\section{SUPPLEMENTARY MATERIAL}

\section{Methods}

\section{Apatite AHe dating}

(U-Th-Sm)/He (AHe) dating was carried out at the University of Melbourne. Apatite was handpicked under a binocular microscope, immersed in ethanol and examined under polarised light to select the most suitable grains (with the least number of mineral impurities). AHe dating is usually performed on clear, euhedral, unfractured grains, but the Catanda apatites are markedly anhedral and fractured. This precludes accurate estimates of grain geometry required for $\alpha$-ejection corrections (Farley et al., 1996). The selected grains were thus mechanically abraded using silicon carbide grit (300-425 $\mu \mathrm{m})$ in a Krogh (1982)-style abrasion cell to remove the outer $\sim 25-30 \mu \mathrm{m}$ (i.e. greater than the typical $\alpha$-ejection distance) of the grains (e.g., Spiegel et al., 2009). The process was halted periodically to monitor abrasion progress. Abrasion of the grain periphery eliminates consideration of issues related to change of radiogenic $4 \mathrm{He}$ concentrations by $\alpha$-ejection or $\alpha$-implantation. Therefore, following removal of at least $\sim 20 \propto \mathrm{m}$ there is no the need to apply ejection corrections, which can be considered close to unity in rapidly cooled samples (Min et al., 2006).

Abraded apatite grains were transferred to small Pt-capsules and outgassed under vacuum at $\sim 900^{\circ} \mathrm{C}$ for 5 minutes, using a semiconductor diode Coherent Quattro FAP laser $(820 \mathrm{~nm})$ with fibre-optic coupling to the sample chamber to provide optimal coupling with samples and heating without melting, ablation or fusion. $4 \mathrm{He}$ contents were determined by isotope dilution with a pure $3 \mathrm{He}$ spike, using a Balzers QMS 200-Prisma quadrupole mass spectrometer. A hot blank was run after each gas extraction to verify complete outgassing of the apatite grains. Most samples yielded negligible amounts of gas after the first reextraction, and for all samples a second re-extraction invariably contributed $<0.5 \%$ of the total measured $4 \mathrm{He}$.

Following the He outgassing step, the apatite grains were dissolved (within their $\mathrm{Pt}$ capsules) in $\mathrm{HNO}_{3}$ for determination of U-Th-Sm concentrations using an Agilent 7700x ICPMS. USGS basalt BCR-2 was used as primary standard. Total uncertainty in measured $4 \mathrm{He} /(\mathrm{U}+\mathrm{Th}+\mathrm{Sm})$ for abraded apatite is $3 \%( \pm 1 \sigma)$. USGS basalt BHVO-2 and Durango apatite were analysed to monitor data quality for U-Th-Sm concentrations and AHe ages, respectively. The results obtained for BHVO-2 are consistent with the 5-year averages (Sm $6075 \mathrm{ppb}[ \pm 0.5 \% ; \pm 1 \mathrm{sd}], \mathrm{U} 424 \mathrm{ppb}[ \pm 0.36 \%]$, Th $1209 \mathrm{ppb}[ \pm 0.35 \%] ; \mathrm{n}=124)$, while four 
AHe ages of Durango apatite acquired with the Catanda samples average $31.2 \pm 1.0 \mathrm{Ma}( \pm$ $2 \sigma$; Table A2), consistent with an AHe age of 31.02 \pm 1.01 Ma for a set of 24 Durango apatite determined at the Caltech He laboratory (McDowell et al., 2005).

\section{Phlogopite $40 \mathrm{Ar} / 39 \mathrm{Ar}$ dating}

The Catanda carbonatites are not ideal candidates for $40 \mathrm{Ar} / 39 \mathrm{Ar}$ geochronology given the common alteration of phlogopite to vermiculite (Tauler et al., 2014) and the presence of glimmerite xenoliths and xenocrystic micas in the studied samples. As an exploratory exercise to determine whether any meaningful $40 \mathrm{Ar} / 39 \mathrm{Ar}$ age information could be extracted from the samples, a small number of apparently microphenocrystic phlogopite grains from lava samples AC-21, -24 and -25 were selected under binocular microscope for $40 \mathrm{Ar} / 39 \mathrm{Ar}$ geochronology. The AC-21 grains appeared to be pervasively altered to vermiculite, but the least altered grains were selected for this study. Following soaking in $5 \% \mathrm{HNO}_{3}$, rinsing in water and then acetone, the samples were wrapped in aluminium foil packets, stacked in a quartz-glass vial along with fluence monitor Alder Creek Rhyolite sanidine (1.18144 \pm 0.00068 Ma, Phillips et al., 2017) and irradiated in the CLICIT facility at the Oregon State University TRIGA reactor for 0.4 MWhr (UM\#61).

The $40 \mathrm{Ar} / 39 \mathrm{Ar}$ analyses were undertaken in the Noble Gas laboratory at the University of Melbourne, using a multi-collector Thermo Fisher Scientific ARGUSVI mass spectrometer linked to a stainless steel gas extraction/purification line and a Photon Machines Fusions 10.6 $\mathrm{CO}_{2}$ laser system (e.g., Phillips and Matchan, 2013). Single-grain step heating analyses were performed on the AC-21 phlogopite grains $(n=5)$. In the case of samples AC24 and -25 , grains were combined for analysis due to small sample size (two aliquots for AC24, one for AC-25). Grains were heated using a $6 \mathrm{~mm}$ homogenized laser beam over a range of 3-30\% laser power, following initial outgassing at $0.5 \%$ laser power to remove adsorbed gas.

Due to the short irradiation time, it was not feasible to include $\mathrm{Ca} / \mathrm{K} / \mathrm{Cl}$ salts/glasses in the same package as the samples. Therefore, correction factors determined for K-glass and $\mathrm{Ca}$-salts contained in package irradiated close in time in the CLICIT facility were used. These are the employed interference correction values: $(36 \mathrm{Ar} / 37 \mathrm{Ar}) \mathrm{Ca} \quad=2.570( \pm 0.002) \times 10-4$; $(39 \mathrm{Ar} / 37 \mathrm{Ar})_{\mathrm{Ca}}=6.62( \pm 0.08) \times 10-4 ;(40 \mathrm{Ar} / 39 \mathrm{Ar}) \mathrm{K}=0.001210( \pm 0.000016)$. Age spectra and inverse isochron diagrams were generated using ISOPLOT/Ex.3.75 (Ludwig, 2012). Plateau ages are defined as including at least $60 \%$ of the $39 \mathrm{Ar}$, distributed over a minimum of three 
contiguous steps and with $40 \mathrm{Ar} / 39 \mathrm{Ar}$ ratios within agreement of the mean at the $95 \%$ confidence level (e.g., Lanphere and Dalrymple, 1978). An atmospheric (40Ar/36Ar)i value of $298.56 \pm 0.62$ (Lee et al., 2006) is assumed.

\section{Phlogopite Rb-Sr dating and $\mathrm{Sr}-\mathrm{Nd}-\mathrm{Hf}$-Pb isotope analyses}

$\mathrm{Rb}-\mathrm{Sr}$ isotope dilution data for phlogopite, as well as $\mathrm{Sr}-\mathrm{Nd}-\mathrm{Hf}-\mathrm{Pb}$ isotope data for apatite, clinopyroxene and groundmass samples were acquired using multi-collector ICP-MS at the University of Melbourne (e.g. Maas et al., 2015; Giuliani et al., 2015). Phlogopite grains were leached with $0.5 \mathrm{M} \mathrm{HNO}_{3}(40 \circ \mathrm{C}, 2 \mathrm{~min})$ or $2 \mathrm{M} \mathrm{HNO}_{3}\left(40_{\circ} \mathrm{C}, 2\right.$ mins) to gently remove easily soluble $\mathrm{Sr}$-rich impurities and generate higher $\mathrm{Rb} / \mathrm{Sr}$ ratios in the residual phlogopite (Brown et al., 1989; Maas, 2003). The residues were dissolved on a hot plate (3:1 HF-HNO3, $6 \mathrm{M} \mathrm{HCl}$ ). The resulting solutions, and the $2 \mathrm{M} \mathrm{HNO}_{3}$ leachates for each of the three phlogopite samples, were equilibrated with a $85 \mathrm{Rb}-84 \mathrm{Sr}$ tracer, followed by extraction of $\mathrm{Rb}$ and Sr using cation exchange and Eichrom Sr resin.

Apatite was cleaned with hot water and dissolved with $5 \mathrm{M} \mathrm{HNO}_{3}$, while clinopyroxene (cleaned with hot $2 \mathrm{M} \mathrm{HNO}_{3}$ ) and chips of groundmass material were dissolved with 3:1 $\mathrm{HF}_{-\mathrm{HNO}_{3}}$ and $6 \mathrm{M} \mathrm{HCl}$. Small splits of each solution were reserved for trace element analyses on an Agilent 7700x quadrupole ICPMS; the remaining solution was used to extract $\mathrm{Pb}, \mathrm{Sr}, \mathrm{Nd}$ and $\mathrm{Hf}$ as required.

Isotopic analyses were carried out on a Nu Plasma multi-collector ICP-MS. Mass bias in unspiked $\mathrm{Sr}, \mathrm{Nd}$ and $\mathrm{Hf}$ isotope analyses was corrected by internal normalization to $86 \mathrm{Sr} / 88 \mathrm{Sr}=0.1194,{ }_{146} \mathrm{Nd} / 144 \mathrm{Nd}=0.7219$ and ${ }_{179} \mathrm{Hf} / 177 \mathrm{Hf}=0.7325$ using the exponential law; final data are reported relative to SRM987 $=0.71023$, La Jolla Nd $=0.511860$ and JMC475 = 0.282160 and have internal precisions (2se) of $\pm 0.000020, \pm 0.000010$ and \pm 0.000008 , respectively. External precision (2sd) is $\pm 0.00004(\mathrm{Sr}), \pm 0.000020(\mathrm{Nd}), \pm 0.000015$ (Hf).

Mass bias in $\mathrm{Pb}$ isotope analyses was corrected by thallium-doping (Woodhead, 2002; SRM981 is assumed to have $206 \mathrm{~Pb} / 204 \mathrm{~Pb}=16.935,{ }_{207} \mathrm{~Pb} / 204 \mathrm{~Pb}=15.489$ and $208 \mathrm{~Pb} / 204 \mathrm{~Pb}=$ 36.701 ) and corrected ratios have external precisions of $\pm 0.04-0.09 \%$ (2sd). Results for USGS basalt BCR-2 acquired at the time the Catanda samples were analysed average

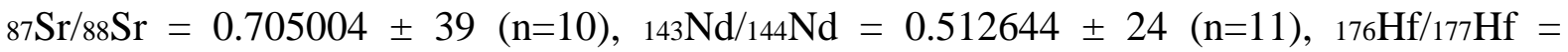
$0.282878 \pm 13(\mathrm{n}=9), 206 \mathrm{~Pb} / 204 \mathrm{~Pb}=18.759 \pm 0.039 \%,{ }_{207} \mathrm{~Pb} / 204 \mathrm{~Pb}=15.621 \pm 0.064 \%$ and ${ }_{208} \mathrm{~Pb} / 204 \mathrm{~Pb}=38.730 \pm 0.087 \%$ ( $2 \mathrm{sd}, \mathrm{n}=22 ; \mathrm{BCR}-2$ not acid-leached); the JNd-1 Nd standard averaged $0.512115 \pm 11(\mathrm{n}=12)$. These results are consistent with TIMS and MC-ICPMS reference values. 
$87 \mathrm{Rb} / 86 \mathrm{Sr}$ obtained by isotope dilution (for phlogopite residues and leachates) have an external precision of $\pm 0.5 \%$ (2sd). Rb-Sr isotope data for several standards (e.g., SRM607 feldspar, GLO-1 glauconite) are consistent with reference values. Likewise, biotite and hornblende from Mt Dromedary monzonite (the source of the GA-1550 and MD-2 reference biotites) produce a model isochron age of $98.63 \pm 0.58 \mathrm{Ma}$ (using the $87 \mathrm{Rb}$ decay constant of Villa et al., 2015), within error of biotite 40Ar-39Ar age constraints (Renne et al., 1998; Spell and McDougall, 2003; Phillips et al., 2017).

Parent-daughter ratios for apatite, clinopyroxene and groundmass were calculated from trace element concentrations measured for splits of the sample solutions (see above) and are assigned uncertainties of $\pm 2 \%$ ( $2 \mathrm{sd}$ ), based on the long-term reproducibility of standard rocks analysed on the same instrument. Modern CHUR is assumed to have $147 \mathrm{Sm} / 144 \mathrm{Nd}=$ $0.196,{ }_{143} \mathrm{Nd} / 144 \mathrm{Nd}=0.512632{ }_{176} \mathrm{Lu} / 177 \mathrm{Hf}=0.0336$ and ${ }_{176} \mathrm{Hf} / 177 \mathrm{Hf}=0.282785$ (Bouvier et al., 2008).

\section{Additional results}

\section{$\mathrm{Rb} / \mathrm{Sr}$ dating of Catanda phlogopite}

Preliminary trace element data for phlogopite phenocrysts in samples AC-21, -24 and -25 indicate high $\mathrm{Sr}$ contents (2000-4000 ppm) and $\mathrm{Rb} / \mathrm{Sr}<1$, presumably related to Sr-rich impurities (apatite, carbonate). Mild acid leaching, employed to remove easily soluble impurities, reduced $\mathrm{Sr}$ contents to $115-227 \mathrm{ppm}$ and raised $\mathrm{Rb} / \mathrm{Sr}$ to $1.8-4.5(87 \mathrm{Rb} / 86 \mathrm{Sr}=$ 5.16- 12.95; Table A2). The analysed leachates ( $\left.2 \mathrm{M} \mathrm{HNO}_{3}\right)$ have lower $\mathrm{Rb} / \mathrm{Sr}$ ratios $(0.05-$ $0.28,{ }_{87} \mathrm{Rb} / 86 \mathrm{Sr}=0.13-0.81$ ). Despite the dispersion in $\mathrm{Rb} / \mathrm{Sr}$, measured $87 \mathrm{Sr} / 86 \mathrm{Sr}$ in the

phlogopite residues is low and relatively uniform (0.70331-0.70397; Table A2). The leachates (0.70346-0.70348; Table A2) and apatite and clinopyroxene phenocrysts from the same samples (0.70309-0.70354; Table A1) have similar present-day $87 \mathrm{Sr} / 86 \mathrm{Sr}$. In the $\mathrm{Rb}-\mathrm{Sr}$ isochron diagram (not shown), the data do not define linear arrays. This suggests that the $\mathrm{Rb}$ Sr systems are very young.

\section{Ar/39Ar dating of Catanda phlogopite}

Results are summarised below with the full dataset located in Tables A4-A6 A summary of age results is provided in Table A5. Uncertainties are stated at the $2 \sigma$ level unless otherwise specified. Although samples were too small to measure 37Ar precisely, this has a negligible impact on the results given the large error on apparent age calculations resulting from extremely low $40 \mathrm{Ar} *$ yields. For this reason, we prefer not to correct for Ca-induced 
interferences (see Table A4 for both versions of the dataset). The large uncertainties in ${ }_{40} \mathrm{Ar} * / 39 \mathrm{Ar}$ ratios (Table A4) are due to extremely small 39Ar contents (small sample size), and high levels of atmospheric argon in the samples.

Phlogopite grains from samples AC-24 and AC-25 yield similar argon isotopic data, with atmospheric argon dominating the $40 \mathrm{Ar}$ signal (40Ar* $\leq 17 \%$ of total $40 \mathrm{Ar}$; Table A4). Mid- to high-temperature heating steps with meaningful 39Ar measurements $(>1 \mathrm{fA}$ 39Ar; $n=$ 6) yield apparent ages ranging from $582 \pm 26 \mathrm{ka}$ (24PHL-1, step 2) to $1.35 \pm 0.23 \mathrm{Ma}$ (24PHL-2, step 2). These data $(n=6)$ are combined for inverse isochron analysis (J-values overlap at the $1 \sigma$-level), revealing the presence of a small amount of excess argon $\left((40 \mathrm{Ar} / 36 \mathrm{Ar})_{\mathrm{i}}=302.01 \pm 0.88 ; \mathrm{MSWD}=0.5, \mathrm{p}=0.73\right)$ and an inverse isochron age of $558 \pm 22$ ka (Fig. A4a). In comparison, the AC-21 grains yield older apparent ages across all heating steps and exhibit higher levels of atmospheric argon contamination $\left(40 \mathrm{Ar}^{*} \leq 3 \%\right.$ of total 40Ar). A weighted mean age of $741 \pm 44 \mathrm{ka}(\mathrm{MSWD}=1.4, \mathrm{p}=0.22)$ is calculated by pooling the concordant $40 \mathrm{Ar} * / 39 \mathrm{Ar}$ values $(\mathrm{n}=7)$ from all five $\mathrm{AC}-21$ grains. The corresponding inverse isochron (Fig. A4b) yields an age of $776 \pm 81 \mathrm{ka}$, with an atmospheric (40Ar/36Ar)i value of $298.18 \pm 0.75$. The age spectrum for 21PHL-1 subtly increases with increasing temperature, ranging from $520 \pm 210$ to $780 \pm 160 \mathrm{ka}$, suggesting that this sample may have experienced $40 \mathrm{Ar}^{*}$ loss but the large analytical uncertainties $(13-40 \% ; 2 \sigma)$ preclude any further comment. A plateau age of $690 \pm 63 \mathrm{ka}(\mathrm{MSWD}=1.5 \mathrm{p}=0.19,84 \%$ of $39 \mathrm{Ar}$; Fig. A4c).

\section{References}

Bouvier, A., Vervoort, J., Patchett, J.P., 2008. The Lu-Hf and Sm-Nd isotopic composition of CHUR: Constraints from unequilibrated chondrites and implications for the bulk composition of terrestrial planets. Earth and Planetary Science Letters 272, 48-57.

Brown, R.W., Allsopp, H.I., Bristow, J.W., Smith, C.B., 1989. Improved precision of Rb-Sr dating of kimberlitic micas: An assessment of a leaching technique. Chemical Geology 79, 125-136.

Farley, K.A., Wolf, R.A., Silver, L.T., 1996. The effects of long alpha-stopping distances on (U-Th)/He ages. Geochimica et Cosmochimica Acta 60, 4223-4229.

Giuliani, A., Phillips, D., Woodhead, J.D., Kamenetsky, V.S., Fiorentini, M.L., Maas, R., Soltys, A., Armstrong, R.S., 2015. Did diamond-bearing orangeites originate from MARID-veined peridotites in the lithospheric mantle? Nature Communications 6:6837 doi: $10.1038 /$ ncomms7837. 
Krogh, T.E., 1982. Improved accuracy of U-Pb zircon ages by the creation of more concordant systems using an air abrasion technique. Geochimica et Cosmochimica Acta 46, 637-649.

Lanphere, M.A., Dalrymple, G.B., 1978. The use of 40Ar/39Ar data in evaluation of disturbed K-Ar systems, Open-File Report VL. U.S. Geological Survey Open File Report.

Lee, J.-Y., Marti, K., Severinghaus, J., Kawamura, K., Yoo, S.-S., Lee, J., Kim, J., 2006. A redetermination of the isotopic abundances of atmospheric Ar. Geochimica et Cosmochimica Acta 70, 4507-4512.

Ludwig, K.R., 2012. User's Manual for Isoplot 3.75: A Geochronological Toolkit for Microsoft Excel. Berkeley Geochronology Center Special Publication No. 6, 75 p.

Maas, R., 2003. Acid leaching of micas: improved Rb-Sr geochronology of disequilibrated rocks from zones of alteration and deformation. Journal of the Virtual Explorer 13, doi: 10.3809/jvirtex.2003.00085.

Maas, R., Grew, E.S., Carson, C.J., 2015. Isotopic constraints (Pb, Rb-Sr, Sm-Nd) on the sources of Early Cambrian pegmatites with boron and beryllium minerals in the Larseman Hills, Prydz Bay, Antarctica. The Canadian Mineralogist 53, 249-272.

McDowell, F.W., McIntosh, W.C., Farley, K.A., 2005. A precise 40Ar-39Ar reference age for the Durango apatite (U-Th)/He and fission-track dating standard. Chemical Geology 214, 249-263.

Min, K., Reiners, P. W., Wolff, J. A., Mundil, R., Winters, R. L., 2006. (U-Th)/He dating of volcanic phenocrysts with high-U-Th inclusions, Jemez Volcanic Field, New Mexico. Chemical Geology 227, 223-235.

Phillips, D., Matchan, E.L., 2013. Ultra-high precision 40Ar/39Ar ages for Fish Canyon Tuff and Alder Creek Rhyolite sanidine: New dating standards required? Geochimica et Cosmochimica Acta 121, 229-239.

Phillips, D., Matchan, E.L., Honda, M., Kuiper, K.F., 2017. Astronomical calibration of 40Ar/39Ar reference minerals using high-precision, multi-collector (ARGUSVI) mass spectrometry. Geochimica et Cosmochimica Acta 196 IS -, 351-369.

Renne, P.R., Swisher, C.C., Deino, A.L., Karner, D.B., Owens, T.L., DePaolo, D.J., 1998. Intercalibration of standards, absolute ages and uncertainties in $40 \mathrm{Ar} / 39 \mathrm{Ar}$ dating. Chemical Geology 145, 117-152.

Spell, T.L. and McDougall, I., 2003. Characterization and calibration of $40 \mathrm{Ar} / 39 \mathrm{Ar}$ dating standards. Chemical Geology 198, 189-211. 
Spiegel, C., Kohn, B., Belton, D., Berner, Z., Gleadow, A., 2009. Apatite (U-Th-Sm)/He thermochronology of rapidly cooled samples: The effect of He implantation. Earth and Planetary Science Letters 285, 105-114.

Tauler. E., Campeny, M., Melgarejo, J.C., Bambi., A., Mangas, J., Manuel., J., 2014. Patrones de formación y de alteración de la vermiculita en las carbonatitas volcánicas de Catanda (Angola). Macla 19, Proceedings of the XXXIV Conference of the Spanish Society of Mineralogy.

Villa, I.M., De Bièvre, P., Holden, N.E., Renne, P.R., 2015. IUPAC-IUGS recommendation on the halflife of ${ }_{87} \mathrm{Rb}$. Geochimica et Cosmochimica Acta 164, 382-385.

Woodhead, J.D., 2002. A simple method for obtaining highly accurate $\mathrm{Pb}$ isotope data by MC-ICP-MS. Journal of Analytical Atomic Spectrometry 17, 1-6. 


\section{Supplementary Tables}

Table A1. Sr-Nd-Hf-Pb isotope compositions in minerals and groundmass of Catanda lavas

\begin{tabular}{|c|c|c|c|c|c|c|c|c|c|}
\hline $\begin{array}{l}\text { Sample } \\
\text { Fraction }\end{array}$ & $\begin{array}{l}\text { AC-21 } \\
\text { apatite }\end{array}$ & $\begin{array}{c}\mathrm{AC}-21 \\
\mathrm{cpx}\end{array}$ & $\begin{array}{c}\text { AC-21 } \\
\text { groundmass }\end{array}$ & $\begin{array}{l}\mathrm{AC}-24 \\
\text { apatite }\end{array}$ & $\begin{array}{c}\mathrm{AC}-24 \\
\mathrm{cpx}\end{array}$ & $\begin{array}{c}\mathrm{AC}-24 \\
\text { groundmass }\end{array}$ & $\begin{array}{l}\text { AC-25 } \\
\text { apatite }\end{array}$ & $\begin{array}{c}\mathrm{AC}-25 \\
\mathrm{cpx}\end{array}$ & $\begin{array}{c}\mathrm{AC}-25 \\
\text { groundmass }\end{array}$ \\
\hline $\mathrm{Rb}$ ppm & 0.04 & 6.20 & & 0.18 & 0.30 & & 0.62 & 95.20 & \\
\hline Sr ppm & 3539 & 601 & & 4274 & 147 & & 3996 & 2861 & \\
\hline $87 \mathrm{Rb} / 86 \mathrm{Sr}$ & 0.00003 & 0.0299 & & 0.00012 & 0.0059 & & 0.00045 & 0.0962 & \\
\hline $87 \mathrm{Sr} / 86 \mathrm{Sr}$ & 0.703363 & 0.703525 & & 0.703460 & 0.703101 & & 0.703537 & 0.703086 & \\
\hline Sm ppm & 79.5 & 6.80 & 28.01 & 169 & 3.86 & 27.08 & 123 & 3.30 & 22.35 \\
\hline $\mathrm{Nd} \mathrm{ppm}$ & 536 & 40.60 & 220 & 1155 & 21.40 & 211 & 839 & 16.27 & 183 \\
\hline $147 \mathrm{Sm} / 144 \mathrm{Nd}$ & 0.0897 & 0.101 & 0.0771 & 0.0885 & 0.109 & 0.0775 & 0.0887 & 0.1230 & 0.0739 \\
\hline $143 \mathrm{Nd} / 144 \mathrm{Nd}$ & 0.512782 & 0.512803 & 0.512790 & 0.512784 & 0.512855 & 0.51 & 0.512783 & 0.512810 & 0.512796 \\
\hline eNd & 2.9 & 3.3 & 3.1 & 3.0 & 4.4 & 3.6 & 2.9 & 3.5 & 3.2 \\
\hline Lu ppm & & 0.08 & 0.32 & & & 0.32 & & 0.04 & 0.24 \\
\hline Hf ppm & & 12.10 & 2.94 & & & 3.10 & & 6.67 & 2.95 \\
\hline $176 \mathrm{Lu} / 177 \mathrm{Hf}$ & & 0.00094 & 0.0155 & & & 0.0147 & & 0.00081 & 0.0115 \\
\hline $176 \mathrm{Hf} / 177 \mathrm{Hf}$ & & 0.282752 & 0.282806 & & & 0.282807 & & 0.282827 & 0.282802 \\
\hline eHf & & -1.2 & 0.7 & & & 0.8 & & 1.5 & 0.6 \\
\hline $\mathrm{U}$ ppm & 2.07 & & 6.77 & & & 6.43 & & & 4.97 \\
\hline Th ppm & 27.51 & & 18.53 & & & 18.43 & & & 14.14 \\
\hline $\mathrm{Pb}$ ppm & 0.53 & & 2.34 & & & 1.37 & & & 2.74 \\
\hline $238 \mathrm{U} / 204 \mathrm{~Pb}$ & 261 & & 193 & & & 314 & & & 20 \\
\hline $232 \mathrm{Th} / 204 \mathrm{~Pb}$ & 3585 & & 547 & & & 931 & & & 354 \\
\hline $206 \mathrm{~Pb} / 204 \mathrm{~Pb}$ & 20.576 & & 20.504 & & & 20.502 & & & 20.093 \\
\hline${ }_{207} \mathrm{~Pb} / 204 \mathrm{~Pb}$ & 15.788 & & 15.808 & & & 15.809 & & & 15.784 \\
\hline $208 \mathrm{~Pb} / 204 \mathrm{~Pb}$ & 39.994 & & 40.176 & & & 40.167 & & & 39.866 \\
\hline $206 \mathrm{~Pb} / 204 \mathrm{Pbi}$ & 20.550 & & 20.485 & & & 20.470 & & & 20.091 \\
\hline $207 \mathrm{~Pb} / 204 \mathrm{Pbi}$ & 15.627 & & 15.689 & & & 15.615 & & & 15.772 \\
\hline $208 \mathrm{~Pb} / 204 \mathrm{Pbi}$ & 39.879 & & 40.158 & & & 40.137 & & & 39.855 \\
\hline
\end{tabular}

trace element abundances and parent/daughter ratios based on trace element analysis of splits taken from the sample solutions age corrections (for $0.65 \mathrm{Ma}$ ) are trivial and not listed, except for $\mathrm{Pb}$ isotope results cpx: clinopyroxene 
Table A2. Rb-Sr isotope dilution results for Catanda phlogopites (plus apatite and clinopyroxene results)

$\begin{array}{llcccc} & & \text { Rb ppm } & \text { Sr ppm } & 87 \mathrm{Rb} / 86 \mathrm{Sr} & 87 \mathrm{Sr} / 86 \mathrm{Sr} \\ & & & & & \\ \text { AC-21 } & \text { phl res 1 } & 513 & 115 & 12.95 & 0.703969 \\ \text { AC-21 } & \text { phl res 2 } & 210 & 118 & 5.164 & 0.703458 \\ \text { AC-21 } & \text { phl L2 } & 431^{*} & 1672^{*} & 0.746 & 0.703471 \\ \text { AC-21 } & \text { apatite } & 0.04 & 3539 & 0.00003 & 0.703363 \\ \text { AC-21 } & \text { cpx } & 6.20 & 601 & 0.0299 & 0.703525 \\ & & & & & \\ \text { AC-24 } & \text { phl res 1 } & 475 & 227 & 6.047 & 0.703380 \\ \text { AC-24 } & \text { phl res 2 } & 378 & 174 & 6.292 & 0.703451 \\ \text { AC-24 } & \text { ph1 L2 } & 169^{*} & 3748^{*} & 0.1301 & 0.703463 \\ \text { AC-24 } & \text { apatite } & 0.18 & 4274 & 0.00012 & 0.703460 \\ \text { AC-24 } & \text { cpx } & 0.30 & 147.0 & 0.0059 & 0.703101 \\ & & & & & \\ \text { AC-25 } & \text { phl res 1 } & 409 & 196 & 6.026 & 0.703425 \\ \text { AC-25 } & \text { phl res 2 } & 459 & 169 & 7.859 & 0.703307 \\ \text { AC-25 } & \text { phl L2 } & 66^{*} & 236^{*} & 0.814 & 0.703475 \\ \text { AC-25 } & \text { apatite } & 0.62 & 3996 & 0.00045 & 0.703537 \\ \text { AC-25 } & \text { cpx } & 95.2 & 2861 & 0.0962 & 0.703086\end{array}$

Abbreviations: phl=phlogopite, phl res1 and phl res2 refer to sets of phlogopite grains picked from same separate,

phl res 1 was leached with $0.5 \mathrm{M}$, phl res 2 was leached with $2 \mathrm{M}$ HNO3; phl L2 refers to $2 \mathrm{M}$ HNO3 leachates; cpx is clinopyroxene

all phlogopite residue and leachate analyses by isotope dilution; $\mathrm{Rb} / \mathrm{Sr}$ for apatite and clinopyroxene from trace element analysis, see Table $\mathrm{A} 1$

*denotes nanograms of $\mathrm{Rb}$ and $\mathrm{Sr}$ in phl L2 leachate fractions: ppm could not be calculated because leachate equivalent masses are unknown 
Table A3. (U-Th-Sm)/He ages of Catanda apatite grains

\begin{tabular}{cccccccc}
\hline Sample no. & Lab. no. & $\begin{array}{c}\text { No. of } \\
\text { crystals } \\
\text { analysed }\end{array}$ & He no. & He $(\mathrm{ncc})$ & $\begin{array}{c}\text { Th/U } \\
\text { ratio }\end{array}$ & aAge $(\mathrm{Ma})$ & $\begin{array}{c}\text { Error }( \pm 2 \sigma) \\
(\mathrm{Ma})\end{array}$ \\
\hline AC-21 & 8971 & 3 & 27059 & 0.047 & 11.86 & $\mathbf{0 . 6 9}$ & $\mathbf{0 . 0 4}$ \\
$\mathrm{AC}-21$ & 9009 & 4 & 27145 & 0.078 & 12.88 & $\mathbf{0 . 8 9}$ & $\mathbf{0 . 0 5}$ \\
$\mathrm{AC}-21$ & 9069 & 7 & 27193 & 0.166 & 12.26 & $\mathbf{0 . 5 8}$ & $\mathbf{0 . 0 3}$ \\
$\mathrm{AC}-21$ & 9070 & 6 & 27195 & 0.208 & 13.29 & $\mathbf{0 . 5 7}$ & $\mathbf{0 . 0 3}$ \\
AC-21 & 11669 & 4 & 36352 & 0.035 & 15.75 & $\mathbf{0 . 6 5}$ & $\mathbf{0 . 0 4}$ \\
& & & & & & $\boldsymbol{b} \mathbf{0 . 6 4}$ & $\mathbf{0 . 1 3}$ \\
& & & & & & & \\
AC-25 & 8989 & 1 & 27083 & 0.017 & 13.34 & $\mathbf{0 . 6 4}$ & $\mathbf{0 . 0 4}$ \\
AC-25 & 9012 & 6 & 27156 & 0.044 & 8.82 & $\mathbf{c 1 . 3 3}$ & $\mathbf{0 . 0 8}$ \\
AC-25 & 11673 & 4 & 36364 & 0.075 & 11.60 & $\mathbf{0 . 6 3}$ & $\mathbf{0 . 0 4}$ \\
AC-25 & 11674 & 6 & 36367 & 0.029 & 11.39 & $\mathbf{0 . 7 6}$ & $\mathbf{0 . 0 5}$ \\
AC-25 & 9072 & 5 & 27199 & 0.068 & 11.35 & $\mathbf{0 . 6 2}$ & $\mathbf{0 . 0 4}$ \\
& & & & & & $\boldsymbol{b} \mathbf{0 . 6 5}$ & $\mathbf{0 . 0 9}$ \\
Durango apatite - standard & & & & & & \\
& & & & & & & \\
Durango & 9074 & 1 & 27204 & 1.308 & 17.32 & $\mathbf{3 2 . 4}$ & $\mathbf{1 . 9}$ \\
Durango & 11658 & 1 & 36180 & 5.357 & 15.27 & $\mathbf{3 1 . 6}$ & $\mathbf{1 . 9}$ \\
Durango & 11675 & 1 & 36289 & 3.867 & 15.18 & $\mathbf{3 1 . 7}$ & $\mathbf{1 . 9}$ \\
Durango & 11684 & 1 & 36400 & 21.672 & 17.25 & $\mathbf{2 9 . 7}$ & $\mathbf{1 . 8}$ \\
& & & & & & $\boldsymbol{b} 31.3$ & $\mathbf{1 . 0}$ \\
& & & & & & & \\
\hline
\end{tabular}

aNote grains were abraded and more than $20 \propto \mathrm{m}$ of the outer surface removed, so no $\alpha$-ejection correction was applied. bWeighted mean age (uncertainties at 95\% confidence level) calculated using Isoplot v. 4.15 (Ludwig, 2012).

cAnalysis excluded from calculation of weighted mean age. 
Table A4. ARGUSVI 40Ar/39Ar Analytical Results for Catanda phlogopite samples 21PHL, 22PHL, 24PHLa,b,c,d

\begin{tabular}{|c|c|c|c|c|c|c|c|c|c|c|c|c|c|c|c|c|c|c|c|c|c|}
\hline $\begin{array}{c}\text { Sample } \\
\text { ID }\end{array}$ & $\begin{array}{c}\text { Step } \\
\text { No }\end{array}$ & $\begin{array}{c}\text { Laser } \\
\text { Power } \\
(\%)\end{array}$ & $\begin{array}{l}40 \mathrm{Ar} \\
\text { (fA) }\end{array}$ & $\pm 1 \sigma$ & $\begin{array}{l}\text { 39Ar } \\
\text { (fA) }\end{array}$ & $\pm 1 \sigma$ & $\begin{array}{l}38 \mathrm{Ar} \\
(\mathrm{fA})\end{array}$ & $\pm 1 \sigma$ & $\begin{array}{l}37 \mathbf{A r} \\
\text { (fA) }\end{array}$ & $\pm 1 \sigma$ & $\begin{array}{l}36 \mathrm{Ar} \\
\text { (fA) }\end{array}$ & $\pm 1 \sigma$ & $\begin{array}{c}39 \mathrm{Ar} \\
\text { (x10-14 } \\
\text { mol }\end{array}$ & $\mathrm{Ca} / \mathrm{K}$ & $\pm 1 \sigma$ & $\% 40 A r^{*}$ & $40 \mathrm{Ar} * / 39 \mathrm{Ar}$ & $\pm 1 \sigma$ & $\begin{array}{c}\text { Cum.\% } \\
\text { 39Ar }\end{array}$ & $\begin{array}{l}\text { Age } \\
\text { (Ma) }\end{array}$ & $\pm 1 \sigma$ \\
\hline \multicolumn{22}{|c|}{$\begin{array}{lll}\mathrm{J} \text { J-Value }= & \mathbf{0 . 0 0 0 1 0 5 0 3 0} & \mathbf{\pm 0 . 0 0 0 0 0 0 0 3 8} \\
\text { (one grain) }\end{array}$} \\
\hline 21PHL-1a & 1 & $3 \%$ & 796.33 & 0.28 & 1.607 & 0.022 & 0.5000 & 0.0005 & 1.52 & 1.83 & 2.6524 & 0.0029 & 0.0057 & 1.66 & 2.00 & 0.56 & 2.76 & 0.56 & 15.68 & 0.52 & 0.11 \\
\hline 21PHL-1b & 2 & $5 \%$ & 860.80 & 0.23 & 1.825 & 0.017 & 0.5400 & 0.0009 & 0.07 & 0.15 & 2.8649 & 0.0050 & 0.0065 & 0.07 & 0.14 & 0.63 & 3.00 & 0.83 & 33.48 & 0.57 & 0.16 \\
\hline $21 \mathrm{PHL}-1 \mathrm{c}$ & 3 & $7 \%$ & 324.39 & 0.08 & 1.621 & 0.032 & 0.2016 & 0.0003 & 0.07 & 0.15 & 1.0698 & 0.0017 & 0.0058 & 0.08 & 0.16 & 1.54 & 3.09 & 0.32 & 49.30 & 0.58 & 0.06 \\
\hline 21PHL-1d & 4 & $9 \%$ & 116.56 & 0.05 & 0.904 & 0.023 & 0.0714 & 0.0003 & 0.07 & 0.15 & 0.3790 & 0.0014 & 0.0032 & 0.14 & 0.28 & 2.91 & 3.75 & 0.49 & 58.12 & 0.71 & 0.09 \\
\hline 21PHL-1e & 5 & $12 \%$ & 218.19 & 0.04 & 2.076 & 0.023 & 0.1324 & 0.0006 & 1.14 & 1.61 & 0.7023 & 0.0030 & 0.0074 & 0.96 & 1.36 & 3.91 & 4.11 & 0.44 & 78.38 & 0.78 & 0.08 \\
\hline 21PHL-1f & 6 & $16 \%$ & 152.01 & 0.03 & 2.100 & 0.023 & 0.0906 & 0.0004 & 2.47 & 1.45 & 0.4808 & 0.0019 & 0.0075 & 2.06 & 1.21 & 5.58 & 4.04 & 0.27 & 98.87 & 0.76 & 0.05 \\
\hline 21PHL-1g & 7 & $30 \%$ & 12.30 & 0.03 & 0.116 & 0.019 & 0.0076 & 0.0001 & 0.07 & 0.15 & 0.0405 & 0.0007 & 0.0004 & 1.11 & 2.22 & 1.67 & 1.77 & 1.73 & 100.00 & 0.34 & 0.33 \\
\hline \multicolumn{22}{|c|}{ Sample 21PHL-2 } \\
\hline 21PHL-2a & 1 & $3 \%$ & 601.21 & 0.09 & 1.182 & 0.021 & 0.3764 & 0.0004 & 0.21 & 1.58 & 1.9970 & 0.0021 & 0.0042 & 0.31 & 2.34 & 0.83 & 4.22 & 0.55 & 16.70 & 0.80 & 0.10 \\
\hline 21PHL-2b & 2 & $30 \%$ & 711.12 & 0.19 & 5.505 & 0.030 & 0.4357 & 0.0006 & 0.53 & 2.16 & 2.3112 & 0.0032 & 0.0195 & 0.17 & 0.69 & 2.97 & 3.83 & 0.18 & 94.49 & 0.73 & 0.03 \\
\hline \multicolumn{2}{|c|}{ Sample 21PHL-3 } & (one grain) & & & & & & & & & & & & & & & & & & & \\
\hline $\begin{array}{l}21 \text { PHL-3a } \\
\end{array}$ & 1 & $3 \%$ & 813.86 & 0.11 & 1.378 & 0.015 & 0.5100 & 0.0011 & 2.73 & 2.00 & 2.7055 & 0.0060 & 0.0049 & 3.47 & 2.54 & 0.75 & 4.44 & 1.30 & 39.93 & 0.84 & 0.25 \\
\hline 21PHL-3b & 2 & $30 \%$ & 398.07 & 0.11 & 2.073 & 0.012 & 0.2453 & 0.0004 & 0.07 & 0.15 & 1.3013 & 0.0021 & 0.0074 & 0.06 & 0.13 & 2.40 & 4.61 & 0.31 & 100.00 & 0.87 & 0.06 \\
\hline \multicolumn{2}{|c|}{ Sample 21PHL-4 } & (one grain) & & & & & & & & & & & & & & & & & & & \\
\hline 21PHL-4a & 1 & $3 \%$ & 523.53 & 0.14 & 0.387 & 0.009 & 0.3285 & 0.0007 & 2.10 & 1.52 & 1.7428 & 0.0035 & 0.0014 & 9.49 & 6.85 & 0.61 & 8.31 & 2.75 & 6.04 & 1.57 & 0.52 \\
\hline 21PHL-4b & 2 & $30 \%$ & $1,364.20$ & 0.31 & 6.026 & 0.022 & 0.8480 & 0.0013 & 1.52 & 1.42 & 4.4985 & 0.0068 & 0.0214 & 0.44 & 0.41 & 1.55 & 3.51 & 0.34 & 100.00 & 0.66 & 0.06 \\
\hline \multicolumn{2}{|c|}{ Sample 21PHL-5 } & (one grain) & & & & & & & & & & & & & & & & & & & \\
\hline 21 PHL-5a & 1 & $3 \%$ & 256.29 & 0.07 & 0.068 & 0.025 & 0.1607 & 0.0002 & 1.60 & 0.87 & 0.8526 & 0.0011 & 0.0002 & 41.49 & 27.38 & 0.68 & 25.84 & 10.76 & 2.69 & 4.89 & 2.03 \\
\hline 21PHL-5b & 2 & $10 \%$ & 1.843 .37 & 0.63 & 2.341 & 0.026 & 1.1596 & 0.0014 & 3.77 & 1.32 & 6.1517 & 0.0074 & 0.0083 & 2.82 & 0.99 & 0.36 & 2.87 & 0.98 & 95.94 & 0.54 & 0.19 \\
\hline 21PHL-5c & 3 & $30 \%$ & 32.23 & 0.02 & 0.102 & 0.028 & 0.0197 & 0.0001 & 2.34 & 1.55 & 0.1046 & 0.0007 & 0.0004 & 40.25 & 28.89 & 3.06 & 9.69 & 3.34 & 100.00 & 1.83 & 0.63 \\
\hline \multirow{2}{*}{\multicolumn{22}{|c|}{$\begin{array}{llll}\text { Sample 24 J-Value }= & 0.000104859 & \pm 0.000000038\end{array}$}} \\
\hline \multicolumn{2}{|c|}{ Sample 24PHL-1 (one grain, thin flake) } & & & & & & & & & & & & & & & & & & & & \\
\hline 24PHL-1a & 1 & $3 \%$ & 26.88 & 0.02 & 0.556 & 0.026 & 0.0158 & 0.0001 & 0.20 & 1.26 & 0.0837 & 0.0008 & 0.0020 & 0.64 & 3.97 & 7.05 & 3.41 & 0.45 & 10.78 & 0.64 & 0.09 \\
\hline 24PHL-1b & 2 & $30 \%$ & 83.17 & 0.03 & 4.603 & 0.020 & 0.0436 & 0.0002 & 0.01 & 0.01 & 0.2311 & 0.0010 & 0.0163 & 0.00 & 0.01 & 17.04 & 3.08 & 0.07 & 100.00 & 0.58 & 0.01 \\
\hline \multicolumn{22}{|c|}{ Sample 24PHL-2 (two grains) } \\
\hline 24 PHL-2a & 1 & $3 \%$ & $1,044.58$ & 0.36 & 0.603 & 0.019 & 0.6503 & 0.0009 & 0.07 & 0.15 & 3.4501 & 0.0050 & 0.0021 & 0.22 & 0.43 & 1.39 & 24.09 & 2.67 & 5.54 & 4.55 & 0.50 \\
\hline $24 \mathrm{PHL}-2 \mathrm{~b}$ & 2 & $7 \%$ & 944.95 & 0.43 & 2.635 & 0.012 & 0.5847 & 0.0010 & 0.97 & 1.97 & 3.1020 & 0.0052 & 0.0094 & 0.64 & 1.31 & 1.99 & 7.14 & 0.61 & 29.75 & 1.35 & 0.12 \\
\hline $24 \mathrm{PHL}-2 \mathrm{c}$ & 3 & $30 \%$ & 197.78 & 0.09 & 7.646 & 0.020 & 0.1092 & 0.0004 & 2.75 & 1.44 & 0.5793 & 0.0021 & 0.0271 & 0.63 & 0.33 & 12.55 & 3.25 & 0.08 & 100.00 & 0.61 & 0.02 \\
\hline \multicolumn{22}{|c|}{$\begin{array}{lc}\text { Sample 25 } & \text { J-Value }=\quad \mathbf{0 . 0 0 0 1 0 4 6} \\
\text { Sample 25PHL-1 (three grains, thin flakes) }\end{array}$} \\
\hline 25PHL-1a & 1 & $3 \%$ & 172.26 & 0.05 & 1.575 & 0.039 & 0.1048 & 0.0003 & 0.74 & 2.80 & 0.5560 & 0.0015 & 0.0056 & 0.82 & 3.11 & 3.63 & 3.97 & 0.30 & 21.22 & 0.75 & 0.06 \\
\hline 25PHL-1b & 2 & $7 \%$ & 247.95 & 0.07 & 4.118 & 0.036 & 0.1469 & 0.0004 & 0.07 & 0.15 & 0.7796 & 0.0020 & 0.0146 & 0.03 & 0.06 & 6.13 & 3.69 & 0.15 & 76.71 & 0.70 & 0.03 \\
\hline $25 \mathrm{PHL}-1 \mathrm{c}$ & 3 & $30 \%$ & 35.33 & 0.03 & 1.729 & 0.039 & 0.0187 & 0.0001 & 1.74 & 1.24 & 0.0992 & 0.0007 & 0.0061 & 1.77 & 1.26 & 16.19 & 3.31 & 0.14 & 100.00 & 0.62 & 0.03 \\
\hline
\end{tabular}

a Atmospheric argon composition of Lee et al. (2006) is assumed for mass-discrimation corrections and for trapped argon composittont

$\mathrm{c}$ Age errors are one sigma uncertainties and exclude uncertainties in the J-value,

Age errors are one sigma uncertainties and exclude uncertainties in the J-value.
$\mathrm{d}$-values are calculated assuming an age of $1.18144 \pm 0.00068 \mathrm{Ma}$ (1s; Phillips et al, 2017.) for Alder Creek sanidine.

e Interference corrections values are: $(36 \mathrm{Ar} / 37 \mathrm{Ar}) \mathrm{Ca}=2.570( \pm 0.002) \times 10-4 ;(39 \mathrm{Ar} / 37 \mathrm{Ar}) \mathrm{Ca}=6.62( \pm 0.08) \times 10-4 ;(40 \mathrm{Ar} / 39 \mathrm{Ar}) \mathrm{K}=0.001210( \pm 0.000016)$

$\mathrm{f}$ Data are corrected for mass spectrometer backgrounds, discrimination and radioactive decay.
$\mathrm{g}$ Data are not corrected for Ca-interference due to small sample size and negligible quantities of $37 \mathrm{Ar}$. 
Table A4. cont.

\begin{tabular}{|c|c|c|c|c|c|c|c|c|c|c|c|c|c|c|c|c|c|c|c|c|c|}
\hline $\begin{array}{c}\text { Sample } \\
\text { ID }\end{array}$ & $\begin{array}{c}\text { Step } \\
\text { No }\end{array}$ & $\begin{array}{c}\text { Laser } \\
\text { Power } \\
(\%)\end{array}$ & $\begin{array}{l}\text { 40Ar } \\
(\mathrm{AA})\end{array}$ & $\pm 1 \sigma$ & $\begin{array}{l}39 \mathrm{Ar} \\
(\mathrm{fA})\end{array}$ & $\pm 1 \sigma$ & $\begin{array}{l}38 \mathrm{Ar} \\
(\mathrm{fA})\end{array}$ & $\pm 1 \sigma$ & $\begin{array}{l}37 \mathrm{Ar} \\
(\mathbf{f A})\end{array}$ & $\pm 1 \sigma$ & $\begin{array}{l}36 \mathrm{Ar} \\
(\mathrm{fA})\end{array}$ & $\pm 1 \sigma$ & $\begin{array}{l}39 \mathrm{Ar} \\
(\mathbf{x 1 0 - 1 4} \\
\text { mol) }\end{array}$ & $\mathrm{Ca} / \mathrm{K}$ & $\pm 1 \sigma$ & $\% 40 \mathrm{Ar} *$ & $40 \mathrm{Ar} * / 39 \mathrm{Ar}$ & $\pm 1 \sigma$ & $\begin{array}{l}\text { Cum.\% } \\
\text { 39Ar }\end{array}$ & $\begin{array}{l}\text { Age } \\
\text { (Ma) }\end{array}$ & $\pm 1 \sigma$ \\
\hline 21PHL-1a & 1 & $3.00 \%$ & 796.33 & 0.28 & 1.61 & 0.02 & 0.5000 & 0.0005 & 0.0 & 0.0 & 2.6528 & 0.0028 & 0.0057 & N/A & N/A & 0.54 & 2.69 & 0.56 & 15.68 & 0.51 & 0.10 \\
\hline 21PHL-1b & 2 & $5.00 \%$ & 860.80 & 0.23 & 1.82 & 0.02 & 0.5400 & 0.0009 & 0.0 & 0.0 & 2.8649 & 0.0050 & 0.0065 & N/A & N/A & 0.63 & 2.99 & 0.83 & 33.48 & 0.57 & 0.16 \\
\hline 21PHL-1c & 3 & $7.00 \%$ & 324.39 & 0.08 & 1.62 & 0.03 & 0.2017 & 0.0003 & 0.0 & 0.0 & 1.0698 & 0.0017 & 0.0058 & N/A & N/A & 1.54 & 3.08 & 0.32 & 49.30 & 0.58 & 0.06 \\
\hline 21PHL-1d & 4 & $9.00 \%$ & 116.56 & 0.05 & 0.90 & 0.02 & 0.0715 & 0.0003 & 0.0 & 0.0 & 0.3791 & 0.0014 & 0.0032 & N/A & N/A & 2.90 & 3.75 & 0.49 & 58.11 & 0.71 & 0.09 \\
\hline 21PHL-1e & 5 & $12.00 \%$ & 218.19 & 0.04 & 2.08 & 0.02 & 0.1324 & 0.0006 & 0.0 & 0.0 & 0.7026 & 0.0030 & 0.0074 & N/A & N/A & 3.87 & 4.06 & 0.43 & 78.37 & 0.77 & 0.08 \\
\hline 21PHL-1f & 6 & $16.00 \%$ & 152.01 & 0.03 & 2.10 & 0.02 & 0.0907 & 0.0003 & 0.0 & 0.0 & 0.4814 & 0.0018 & 0.0075 & N/A & N/A & 5.45 & 3.94 & 0.27 & 98.87 & 0.75 & 0.05 \\
\hline 21PHL-1g & 7 & $30.00 \%$ & 12.30 & 0.03 & 0.12 & 0.02 & 0.0076 & 0.0001 & 0.0 & 0.0 & 0.0405 & 0.0007 & 0.0004 & $\mathrm{~N} / \mathrm{A}$ & N/A & 1.62 & 1.72 & 1.73 & \multicolumn{3}{|c|}{$\begin{array}{l}100.00 \\
\text { Total gas age: } 652 \pm 18 \mathrm{ka}(2 \sigma)\end{array}$} \\
\hline 21PHL-2a & 1 & $3.00 \%$ & 601.21 & 0.09 & 1.18 & 0.02 & 0.3764 & 0.0004 & 0.0 & 0.0 & 1.9970 & 0.0021 & 0.0042 & N/A & N/A & 0.83 & 4.21 & 0.54 & 16.70 & 0.80 & 0.10 \\
\hline 21PHL-2b & 2 & $30.00 \%$ & 711.12 & 0.19 & $\begin{array}{l}5.50 \\
6.69\end{array}$ & 0.03 & 0.4357 & 0.0006 & 0.0 & 0.0 & 2.3113 & 0.0031 & 0.0195 & N/A & N/A & $\begin{array}{l}0.03 \\
2.96\end{array}$ & $\begin{array}{l}4.81 \\
3.82 \\
4\end{array}$ & 0.17 & \multicolumn{3}{|c|}{$\begin{array}{ccc}94.47 & 0.72 & 0.03 \\
\text { Total gas age: } & \mathbf{7 4 0} \pm \mathbf{9 0} \mathbf{~} \mathbf{~ a ~}(\mathbf{2 \sigma} \sigma)\end{array}$} \\
\hline 21PHL-3a & 1 & $3.00 \%$ & 813.86 & 0.11 & 1.38 & 0.02 & 0.5101 & 0.0011 & 0.0 & 0.0 & 2.7062 & 0.0060 & 0.0049 & N/A & N/A & 0.73 & 4.29 & 1.30 & 39.96 & 0.81 & 0.24 \\
\hline 21PHL-3b & 2 & $30.00 \%$ & 398.07 & 0.11 & 2.07 & 0.01 & 0.2453 & 0.0004 & 0.0 & 0.0 & 1.3013 & 0.0021 & 0.0074 & $\mathrm{~N} / \mathrm{A}$ & $\mathrm{N} / \mathrm{A}$ & 2.40 & 4.60 & 0.31 & \multirow{2}{*}{\multicolumn{3}{|c|}{$\begin{array}{c}100.00 \quad 00.870 .06 \\
\text { Total gas age: } 850 \pm 270 \mathrm{ka}(2 \sigma)\end{array}$}} \\
\hline & & & & & & & & & & & & & & & & & & 0.01 & & & \\
\hline 21PHL-4a & 1 & $3.00 \%$ & 523.53 & 0.14 & 0.39 & 0.01 & 0.3286 & 0.0007 & 0.0 & 0.0 & 1.7433 & 0.0035 & 0.0014 & N/A & N/A & 0.58 & 7.86 & 2.72 & 6.06 & 1.49 & 0.49 \\
\hline 21PHL-4b & 2 & $30.00 \%$ & $1,364.20$ & 0.31 & 6.03 & 0.02 & 0.8480 & 0.0013 & 0.0 & 0.0 & 4.4989 & 0.0068 & 0.0214 & N/A & N/A & 1.54 & 3.49 & 0.34 & 100.00 & 0.66 & 0.06 \\
\hline 21PHL-5a & 1 & $3.00 \%$ & 256.29 & 0.07 & 0.07 & 0.03 & 0.1608 & 0.0002 & 0.0 & 0.0 & 0.8530 & 0.0011 & 0.0002 & N/A & $\mathrm{N} / \mathrm{A}$ & 0.63 & 23.64 & 9.84 & 2.73 & 4.47 & 1.70 \\
\hline 21PHL-5b & 2 & $10.00 \%$ & $1,843.37$ & 0.63 & 2.34 & 0.03 & 1.1598 & 0.0014 & 0.0 & 0.0 & 6.1527 & 0.0074 & 0.0083 & N/A & N/A & 0.35 & 2.74 & 0.98 & 95.89 & 0.52 & 0.18 \\
\hline 21PHL-5c & 3 & $30.00 \%$ & 32.23 & 0.02 & 0.10 & 0.03 & 0.0198 & 0.0001 & 0.0 & 0.0 & 0.1052 & 0.0005 & 0.0004 & N/A & N/A & 2.51 & 7.80 & 2.64 & 100.00 & 1.48 & 0.40 \\
\hline 24PHL-1a & 1 & $3.00 \%$ & 26.88 & 0.02 & 0.56 & 0.03 & 0.0158 & 0.0001 & 0.0 & 0.0 & 0.0837 & 0.0007 & 0.0020 & N/A & N/A & 7.00 & 3.38 & 0.42 & 10.79 & 0.64 & 0.08 \\
\hline 24PHL-1b & 2 & $30.00 \%$ & 83.17 & 0.03 & 4.60 & 0.02 & 0.0436 & 0.0002 & 0.0 & 0.0 & 0.2311 & 0.0010 & 0.0163 & N/A & N/A & 17.04 & 3.08 & 0.07 & 100.00 & 0.58 & 0.01 \\
\hline 24PHL-2a & 1 & $3.00 \%$ & $1,044.58$ & 0.36 & 0.60 & 0.02 & 0.6503 & 0.0009 & 0.0 & 0.0 & 3.4501 & 0.0050 & 0.0021 & N/A & N/A & 1.39 & 24.07 & 2.67 & 5.54 & 4.55 & 0.50 \\
\hline 24PHL-2b & 2 & $7.00 \%$ & 944.95 & 0.43 & 2.64 & 0.01 & 0.5848 & 0.0010 & 0.0 & 0.0 & 3.1022 & 0.0052 & 0.0094 & $\mathrm{~N} / \mathrm{A}$ & N/A & 1.98 & 7.11 & 0.61 & 29.75 & 1.34 & 0.11 \\
\hline 24PHL-2c & 3 & $30.00 \%$ & 197.78 & 0.09 & 7.65 & 0.02 & 0.1093 & 0.0004 & 0.0 & 0.0 & 0.5800 & 0.0020 & 0.0271 & N/A & N/A & 12.44 & 3.22 & 0.08 & $\begin{array}{c}100.00 \\
\text { Total gas age }\end{array}$ & $\begin{array}{c}0.61 \\
00 \pm 80 \mathrm{ka}(2 \sigma\end{array}$ & $\left.{ }^{0}\right) .02$ \\
\hline 25PHL-1a & 1 & $3.00 \%$ & 172.26 & 0.05 & 1.58 & 0.04 & 0.1048 & 0.0002 & 0.0 & 0.0 & 0.5562 & 0.0013 & 0.0056 & N/A & $\mathrm{N} / \mathrm{A}$ & 3.60 & 3.93 & 0.27 & 21.22 & 0.74 & 0.05 \\
\hline 25PHL-1b & 2 & $7.00 \%$ & 247.95 & 0.07 & 4.12 & 0.04 & 0.1470 & 0.0004 & 0.0 & 0.0 & 0.7796 & 0.0020 & 0.0146 & N/A & N/A & 6.13 & 3.69 & 0.15 & 76.70 & 0.70 & 0.03 \\
\hline $25 \mathrm{PHL}-1 \mathrm{c}$ & 3 & $30.00 \%$ & 35.33 & 0.03 & 1.73 & 0.04 & 0.0188 & 0.0001 & 0.0 & 0.0 & 0.0996 & 0.0006 & 0.0061 & N/A & N/A & 15.81 & 3.23 & 0.12 & 100.00 & 0.61 & 0.02 \\
\hline
\end{tabular}




\begin{tabular}{|c|c|c|c|c|c|c|c|c|c|c|c|c|c|c|c|c|c|c|}
\hline \multicolumn{11}{|c|}{$\begin{array}{l}\text { Table A4. cont. } \\
\text { Background Correction }\end{array}$} & \multicolumn{8}{|c|}{ ARGUSVI Detector Sensitivity and Discrimination Corrections } \\
\hline Blank no. & $\begin{array}{l}40 \mathrm{Ar} \\
\text { (fA) }\end{array}$ & $\pm 1 \sigma$ & $\begin{array}{l}39 \mathrm{Ar} \\
\text { (fA) }\end{array}$ & $\pm 1 \sigma$ & $\begin{array}{l}\text { 38Ar } \\
\text { (fA) }\end{array}$ & $\pm 1 \sigma$ & $\begin{array}{l}37 \mathrm{Ar} \\
(\mathrm{fA})\end{array}$ & $\pm 1 \sigma$ & $\begin{array}{l}36 \mathrm{Ar} \\
\text { (fA) }\end{array}$ & $\pm 1 \sigma$ & $\begin{array}{c}\mathrm{H} 1 / \mathrm{Ax} \\
{[40]}\end{array}$ & $\begin{array}{c}\text { H1/L1 } \\
{[40]}\end{array}$ & $\begin{array}{c}\mathrm{H} 1 / \mathrm{L} 2 \\
{[40]}\end{array}$ & $\underset{(1 \mathbf{a m u})}{\mathrm{AX}}$ & $\begin{array}{c}\mathrm{L1} \\
(\mathbf{l a m u})\end{array}$ & $\begin{array}{c}\mathrm{L} 2 \\
(1 \mathrm{amu})\end{array}$ & H1/CDD & $\begin{array}{l} \pm 1 \sigma \\
(\%)\end{array}$ \\
\hline EXB\#57 & 2.481 & 0.028 & 0.077 & 0.016 & -0.026 & 0.040 & 0.002 & 0.013 & 0.01591 & 0.00028 & 1.00121689 & 0.99890499 & 0.99378531 & 0.99279355 & 0.99079307 & 0.99352078 & 320.402846 & 0.09594157 \\
\hline ЕXB\#57 & 2.481 & 0.028 & 0.077 & 0.016 & -0.026 & 0.040 & 0.002 & 0.013 & 0.01591 & 0.00028 & 1.00121689 & 0.99890499 & 0.99378531 & 0.99279355 & 0.99079307 & 0.99352078 & 320.402846 & 0.09594157 \\
\hline EXB\#58 & 2.547 & 0.024 & 0.086 & 0.020 & -0.065 & 0.026 & 0.021 & 0.007 & 0.01670 & 0.00026 & 1.00121689 & 0.99890499 & 0.99378531 & 0.99279355 & 0.99079307 & 0.99352078 & 320.402846 & 0.09594157 \\
\hline EXB\#58 & 2.547 & 0.024 & 0.086 & 0.020 & -0.065 & 0.026 & 0.021 & 0.007 & 0.01670 & 0.00026 & 1.00121689 & 0.99890499 & 0.99378531 & 0.99279355 & 0.99079307 & 0.99352078 & 320.402846 & 0.09594157 \\
\hline EXB\#59 & 2.185 & 0.016 & 0.056 & 0.018 & $\begin{array}{l}-0.003 \\
-0.021\end{array}$ & $\begin{array}{l}0.020 \\
0.026\end{array}$ & $\begin{array}{l}-0.011 \\
-0.11\end{array}$ & 0.012 & 0.01573 & 0.00009 & $\begin{array}{l}1.00121689 \\
1.009\end{array}$ & 0.99890499 & 0.99378531 & 0.99279355 & 0.99079307 & 0.99352078 & 320.402846 & 0.09594157 \\
\hline EXB\#59 & 2.185 & 0.016 & 0.056 & 0.018 & -0.021 & 0.026 & -0.011 & 0.012 & 0.01573 & 0.00009 & 1.00121689 & 0.99890499 & 0.99378531 & 0.99279355 & 0.99079307 & 0.99352078 & 320.402846 & 0.09594157 \\
\hline EXB\#60 & 2.575 & 0.026 & 0.068 & 0.016 & -0.069 & 0.013 & 0.019 & 0.023 & 0.01591 & 0.00035 & 1.00121689 & 0.99890499 & 0.99378531 & 0.99279355 & 0.99079307 & 0.99352078 & 320.402846 & 0.09594157 \\
\hline EXB\#62 & 1.934 & 0.013 & 0.035 & 0.019 & -0.068 & 0.024 & 0.016 & 0.019 & 0.01324 & 0.00031 & 1.00121689 & 0.99890499 & 0.99378531 & 0.99279355 & 0.99079307 & 0.99352078 & 320.402846 & 0.09594157 \\
\hline EXB\#62 & 1.934 & 0.013 & 0.035 & 0.019 & -0.068 & 0.024 & 0.016 & 0.019 & 0.01324 & 0.00031 & 1.00121689 & 0.99890499 & 0.99378531 & 0.99279355 & 0.99079307 & 0.99352078 & 320.402846 & 0.09594157 \\
\hline EXB\#63 & 1.849 & 30 & 0.077 & 0.008 & -0.035 & 0.010 & .005 & 0.012 & 1362 & 0.00026 & 1.00121689 & 0.99890499 & 0.99378531 & 0.99279355 & 0.99079307 & 0.99352078 & 320.402846 & 0.09594157 \\
\hline EXB\#63 & 1.849 & 0.030 & 0.077 & 0.008 & -0.035 & 0.010 & -0.005 & 0.012 & 0.01362 & 0.00026 & 1.00121689 & 0.99890499 & 0.99378531 & 0.99279355 & 0.99079307 & 0.99352078 & 320.402846 & 0.09594157 \\
\hline EXB\#63 & 1.849 & 0.030 & 0.077 & 0.008 & -0.035 & 0.010 & -0.005 & 0.012 & 0.01362 & 0.00026 & 1.00121689 & 0.99890499 & 0.99378531 & 0.99279355 & 0.99079307 & 0.99352078 & 320.402846 & 0.09594157 \\
\hline EXB\#64 & 2.632 & 0.014 & 0.027 & 0.016 & -0.034 & 0.017 & 0.025 & 0.013 & 0.01619 & 0.00029 & 1.00121689 & 0.99890499 & 0.99378531 & 0.99279355 & 0.99079307 & 0.99352078 & 320.402846 & 0.09594157 \\
\hline EXB\#65 & 1.975 & 0.014 & 0.033 & 0.021 & -0.09 & 0.005 & 0.008 & 0.008 & 01356 & 0.00028 & 1.00121689 & 0.99890499 & 0.99378531 & 0.99279355 & 0.99079307 & 0.99352078 & 320.402846 & 0.09594157 \\
\hline $\begin{array}{l}\text { EXB\#\#3 } \\
\text { EXB\#65 }\end{array}$ & 1.975 & $\begin{array}{l}0.014 \\
0.014\end{array}$ & $\begin{array}{l}0.033 \\
0.033\end{array}$ & $\begin{array}{l}0.021 \\
0.021\end{array}$ & $\begin{array}{l}-0.093 \\
-0.093\end{array}$ & $\begin{array}{l}0.005 \\
0.005\end{array}$ & $\begin{array}{l}0.008 \\
0.008\end{array}$ & $\begin{array}{l}0.008 \\
0.008\end{array}$ & $\begin{array}{l}0.01350 \\
0.01356\end{array}$ & $\begin{array}{l}0.0002828 \\
0.0002\end{array}$ & $\begin{array}{l}1.00121689 \\
1.00121689\end{array}$ & $\begin{array}{l}0.9988904999 \\
0.9980499\end{array}$ & 0.993778531 & 0.99279355 & 0.99079307 & $\begin{array}{l}0.99532018 \\
0.99352078\end{array}$ & $\begin{array}{l}320.402840 \\
320.402846\end{array}$ & 0.09594157 \\
\hline EXB\#65 & 1.975 & 0.014 & 0.033 & 0.021 & -0.093 & 0.005 & 0.008 & 0.008 & 0.01356 & 0.00028 & 1.00121689 & 0.99890499 & 0.99378531 & 0.99279355 & 0.99079307 & 0.99352078 & 320.402846 & 0.09594157 \\
\hline EXB\#65 & 1.975 & 0.014 & 0.033 & 0.021 & -0.093 & 0.005 & 0.008 & 0.008 & 0.01356 & 0.00028 & 1.00121689 & 0.99890499 & 0.99378531 & 0.99279355 & 0.99079307 & 0.99352078 & 320.402846 & 0.09594157 \\
\hline ЕXB\#\#66 & 1.813 & 0.025 & 0.048 & 0.007 & -0.015 & 0.012 & 0.029 & 0.018 & 0.01340 & 0.00021 & 1.00121689 & 0.99890499 & 0.99378531 & 0.99279355 & 0.99079307 & 0.99352078 & 320.402846 & 0.09594157 \\
\hline EXB\#66 & 1.813 & 0.025 & 0.048 & 0.007 & -0.01 & 0.012 & 0.029 & 0.018 & 0.01340 & 0.00021 & 1.00121689 & 0.99890499 & 0.99378531 & 0.99279355 & 0.99079307 & 0.99352078 & 320.402846 & 0.09594157 \\
\hline $\begin{array}{l}\text { EXDE+100 } \\
\text { EXB } \# 66\end{array}$ & 1.813 & $\begin{array}{l}0.025 \\
0.025\end{array}$ & $\begin{array}{l}0.048 \\
0.048\end{array}$ & 0.007 & $\begin{array}{l}-0.013 \\
-0.015\end{array}$ & $\begin{array}{l}0.012 \\
0.012\end{array}$ & $\begin{array}{l}0.029 \\
0.029\end{array}$ & $\begin{array}{l}0.018 \\
0.018\end{array}$ & $\begin{array}{l}0.01340 \\
0.01340\end{array}$ & $\begin{array}{l}0.00021 \\
0.00021\end{array}$ & $\begin{array}{l}1.00121089 \\
1.00121689\end{array}$ & $\begin{array}{l}0.998890499 \\
0.9989\end{array}$ & 0.99378531 & 0.99279355 & 0.99079307 & 0.99352078 & 320.402840 & 0.09594157 \\
\hline EXB\#66 & 1.813 & 0.025 & 0.048 & 0.007 & -0.015 & 0.012 & 0.029 & 0.018 & 0.01340 & 0.00021 & 1.00121689 & 0.99890499 & 0.99378531 & 0.99279355 & 0.99079307 & 0.99352078 & 320.402846 & 0.09594157 \\
\hline EXB: & 2. & & 0 & & 0. & & & & & & 1.0 & & 0.9 & & & 078 & 320. & 0.095 \\
\hline ЕXB\#67 & 2.091 & 0.029 & 0.061 & 0.032 & 0.009 & 0.016 & 0.006 & 0.011 & 0.01542 & 0.00042 & 1.00121689 & 0.99890499 & 0.99378531 & 0.99279355 & 0.99079307 & 0.99352078 & 320.402846 & 0.09594157 \\
\hline EXB\#67 & 2.091 & 0.029 & 0.061 & 0.032 & 0.009 & 0.016 & 0.006 & 0.011 & 0.01542 & 0.00042 & 1.00121689 & 0.99890499 & 0.99378531 & 0.99279355 & 0.99079307 & 0.99352078 & 320.402846 & 0.09594157 \\
\hline
\end{tabular}


Table A5. Summary of Ar-Ar age results calculated for Catanda phlogopite (samples 21PHL, 24PHL and 25PHL)

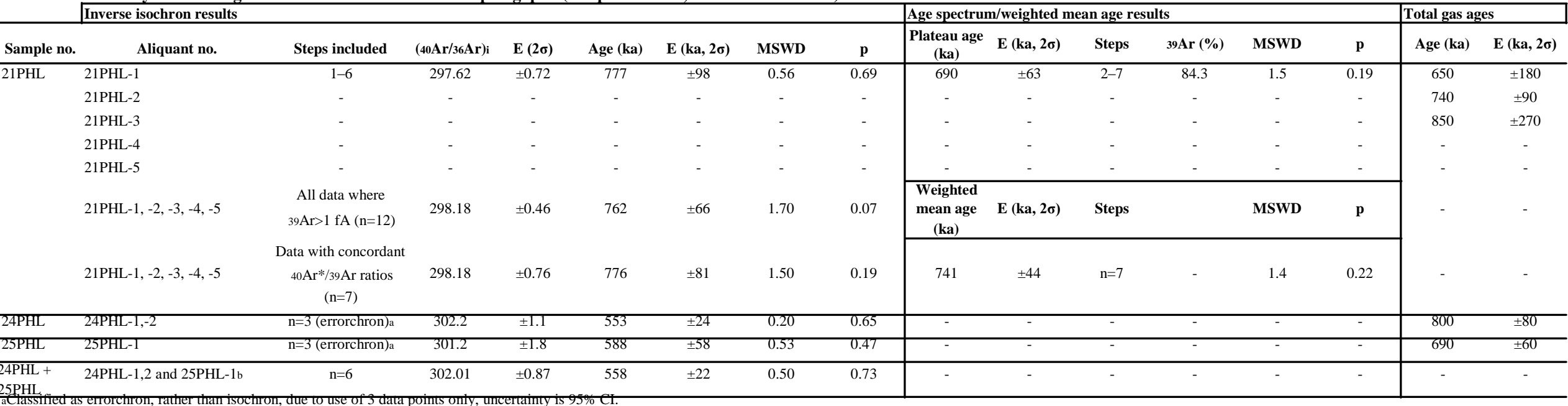

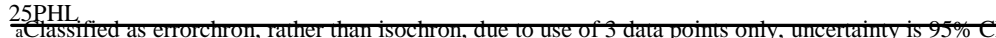

bJ-value of $0.00104689 \pm 0.037 \%$ (25PHL value) was used to calculate age for 24PHL-25PHL composite inverse isochron. 
Table A6. ARGUSVI 40Ar/39Ar Analytical Results for Alder Creek Rhyolite sanidine fusionsa,b

\begin{tabular}{|c|c|c|c|c|c|c|c|c|c|c|c|c|c|c|c|c|c|c|}
\hline $\begin{array}{c}\text { Sample } \\
\text { ID }\end{array}$ & $\begin{array}{l}\text { Step } \\
\text { No }\end{array}$ & $\begin{array}{l}\text { Laser } \\
\text { Power }\end{array}$ & $\begin{array}{l}40 \mathbf{A r} \\
\text { (fA) }\end{array}$ & $\pm 1 \sigma$ & $\begin{array}{l}39 \mathbf{A r} \\
\text { (fA) }\end{array}$ & $\pm \mathbf{1 \sigma}$ & $\begin{array}{l}38 \mathrm{Ar} \\
\text { (fA) }\end{array}$ & $\pm 1 \sigma$ & $\begin{array}{l}37 \mathbf{A r} \\
(\mathbf{f A})\end{array}$ & $\pm 1 \sigma$ & $\begin{array}{l}36 \mathrm{Ar} \\
\text { (fA) }\end{array}$ & $\pm 1 \sigma$ & $\begin{array}{c}39 \mathrm{Ar} \\
(\mathrm{x} 10-14 \\
\mathrm{mol}) \\
\end{array}$ & $\mathrm{Ca} / \mathbf{K}$ & $\pm 1 \sigma$ & $\% 40 \mathrm{Ar}$ & $40 \mathrm{Ar} * / 39 \mathrm{Ar}$ & $\pm 1 \sigma$ \\
\hline \multicolumn{19}{|c|}{ Sample AC8 (three-grain aliquots) } \\
\hline AC8-1 & 1 & $35 \%$ & 489.30 & 0.04 & 72.03 & 0.05 & 0.0257 & 0.0003 & 2.6374 & 1.8899 & 0.1363 & 0.0014 & 0.2557 & 0.064 & 0.046 & 91.68 & 6.2283 & 0.0073 \\
\hline AC8-2 & 1 & $35 \%$ & 473.33 & 0.13 & 69.62 & 0.04 & 0.0251 & 0.0002 & 0.0729 & 0.1458 & 0.1333 & 0.0010 & 0.2471 & 0.002 & 0.004 & 91.59 & 6.2274 & 0.0058 \\
\hline AC $8-3$ & 1 & $35 \%$ & 606.62 & 0.12 & 89.83 & 0.05 & 0.0300 & 0.0002 & 3.6744 & 2.7247 & 0.1591 & 0.0012 & 0.3189 & 0.072 & 0.053 & 92.17 & 6.2240 & 0.0053 \\
\hline AC8-4 & 1 & $35 \%$ & 576.50 & 0.18 & 89.09 & 0.03 & 0.0132 & 0.0002 & 0.7241 & 2.5232 & 0.0698 & 0.0009 & 0.3163 & 0.014 & 0.050 & 96.38 & 6.2371 & 0.0044 \\
\hline AC8-5 & 1 & $35 \%$ & 527.63 & 0.11 & 76.95 & 0.02 & 0.0309 & 0.0001 & 0.0730 & 0.1459 & 0.1638 & 0.0008 & 0.2732 & 0.002 & 0.003 & 90.73 & 6.2214 & 0.0037 \\
\hline \multirow{2}{*}{\multicolumn{19}{|c|}{ Weighted mean: $6.2272 \pm 0.0044(2 \sigma) ; M S W D=2.0, p=0$. }} \\
\hline \multicolumn{5}{|c|}{ Sample AC9 (three-grain aliquots) } & & & & & & & & & & & & & & \\
\hline AC9-1 & 1 & $35 \%$ & 384.71 & 0.08 & 59.09 & 0.02 & 0.0090 & 0.0001 & 4.4979 & 2.0392 & 0.0478 & 0.0006 & 0.2098 & 0.133 & 0.060 & 96.29 & 6.2696 & 0.0042 \\
\hline AC9-2 & 1 & $35 \%$ & 520.09 & 0.10 & 79.17 & 0.03 & 0.0150 & 0.0002 & 2.3338 & 1.6513 & 0.0795 & 0.0010 & 0.2811 & 0.052 & 0.036 & 95.44 & 6.2690 & 0.0045 \\
\hline AC9-3 & 1 & $35 \%$ & 600.46 & 0.11 & 90.01 & 0.05 & 0.0229 & 0.0001 & 1.0941 & 1.4692 & 0.1213 & 0.0007 & 0.3195 & 0.021 & 0.029 & 93.97 & 6.2689 & 0.0044 \\
\hline AC9-4 & 1 & $35 \%$ & 351.94 & 0.10 & 52.67 & 0.03 & 0.0141 & 0.0002 & 2.1657 & 2.2360 & 0.0750 & 0.0011 & 0.1870 & 0.072 & 0.074 & 93.64 & 6.2576 & 0.0072 \\
\hline AC9-5 & 1 & $35 \%$ & 512.39 & 0.28 & 71.62 & 0.05 & 0.0414 & 0.0002 & 4.4124 & 1.5657 & 0.2197 & 0.0009 & 0.2542 & 0.108 & 0.038 & 87.20 & 6.2387 & 0.0070 \\
\hline
\end{tabular}

Data are corrected for mass spectrometer backgrounds, discrimination and radioactive decay. Atmospheric argon composition of Lee et al. (2006) is assumed.

b Interference corrections values are: $(36 \mathrm{Ar} / 37 \mathrm{Ar}) \mathrm{Ca}=2.570( \pm 0.002) \times 10-4 ;(39 \mathrm{Ar} / 37 \mathrm{Ar}) \mathrm{Ca}=6.62( \pm 0.08) \times 10-4 ;(40 \mathrm{Ar} / 39 \mathrm{Ar}) \mathrm{K}=0.001210( \pm 0.000016)$. 